\title{
Ensemble simulations of the role of the stratosphere in the attribution of northern extratropical tropospheric ozone variability
}

\author{
P. Hess ${ }^{1}$, D. Kinnison ${ }^{2}$, and Q. Tang ${ }^{3}$ \\ ${ }^{1}$ Cornell University, Department of Biological and Environmental Engineering, Ithaca, NY, USA \\ ${ }^{2}$ National Center for Atmospheric Research, Boulder, CO, USA \\ ${ }^{3}$ Lawrence Livermore National Laboratory, Livermore, CA, USA \\ Correspondence to: P. Hess (pgh25@cornell.edu)
}

Received: 19 June 2014 - Published in Atmos. Chem. Phys. Discuss.: 8 August 2014

Revised: 21 January 2015 - Accepted: 22 January 2015 - Published: 4 March 2015

\begin{abstract}
Despite the need to understand the impact of changes in emissions and climate on tropospheric ozone, the attribution of tropospheric interannual ozone variability to specific processes has proven difficult. Here, we analyze the stratospheric contribution to tropospheric ozone variability and trends from 1953 to 2005 in the Northern Hemisphere $(\mathrm{NH})$ mid-latitudes using four ensemble simulations of the free running (FR) Whole Atmosphere Community Climate Model (WACCM). The simulations are externally forced with observed time-varying (1) sea-surface temperatures (SSTs), (2) greenhouse gases (GHGs), (3) ozone depleting substances (ODS), (4) quasi-biennial oscillation (QBO), (5) solar variability (SV) and (6) stratospheric sulfate surface area density (SAD). A detailed representation of stratospheric chemistry is simulated, including the ozone loss due to volcanic eruptions and polar stratospheric clouds. In the troposphere, ozone production is represented by $\mathrm{CH}_{4}-\mathrm{NO}_{\mathrm{x}}$ smog chemistry, where surface chemical emissions remain interannually constant. Despite the simplicity of its tropospheric chemistry, at many $\mathrm{NH}$ measurement locations, the interannual ozone variability in the FR WACCM simulations is significantly correlated with the measured interannual variability. This suggests the importance of the external forcing applied in these simulations in driving interannual ozone variability. The variability and trend in the simulated 1953-2005 tropospheric ozone from 30 to $90^{\circ} \mathrm{N}$ at background surface measurement sites, $500 \mathrm{hPa}$ measurement sites and in the area average are largely explained on interannual timescales by changes in the $30-90^{\circ} \mathrm{N}$ area averaged flux of ozone across the $100 \mathrm{hPa}$ surface and changes in tropospheric methane concentrations. The average sensi-
\end{abstract}

tivity of tropospheric ozone to methane (percent change in ozone to a percent change in methane) from 30 to $90^{\circ} \mathrm{N}$ is 0.17 at $500 \mathrm{hPa}$ and 0.21 at the surface; the average sensitivity of tropospheric ozone to the $100 \mathrm{hPa}$ ozone flux (percent change in ozone to a percent change in the ozone flux) from 30 to $90^{\circ} \mathrm{N}$ is 0.19 at $500 \mathrm{hPa}$ and 0.11 at the surface. The $30-90^{\circ} \mathrm{N}$ simulated downward residual velocity at $100 \mathrm{hPa}$ increased by $15 \%$ between 1953 and 2005. However, the impact of this on the $30-90^{\circ} \mathrm{N} 100 \mathrm{hPa}$ ozone flux is modulated by the long-term changes in stratospheric ozone. The ozone flux decreases from 1965 to 1990 due to stratospheric ozone depletion, but increases again by approximately $7 \%$ from 1990 to 2005. The first empirical orthogonal function of interannual ozone variability explains from $40 \%$ (at the surface) to over $80 \%$ (at $150 \mathrm{hPa}$ ) of the simulated ozone interannual variability from 30 to $90^{\circ} \mathrm{N}$. This identified mode of ozone variability shows strong stratosphere-troposphere coupling, demonstrating the importance of the stratosphere in an attribution of tropospheric ozone variability. The simulations, with no change in emissions, capture almost $50 \%$ of the measured ozone change during the 1990s at a variety of locations. This suggests that a large portion of the measured change is not due to changes in emissions, but can be traced to changes in large-scale modes of ozone variability. This emphasizes the difficulty in the attribution of ozone changes, and the importance of natural variability in understanding the trends and variability of ozone. We find little relation between the El Niño-Southern Oscillation (ENSO) index and large-scale tropospheric ozone variability over the long-term record. 


\section{Introduction}

Global change will impact both tropospheric and stratospheric ozone concentrations. Ozone acts as a potent oxidant deleterious to human health, ecosystem and agricultural productivity; it shields the Earth's surface from harmful ultraviolet radiation; it is a greenhouse gas itself, and through its complex photochemistry regulates the lifetime of other greenhouse gases. Because of tropospheric ozone's importance as a surface pollutant the emissions of ozone precursors are regulated in many countries while the Montreal Protocol and its amendments regulate emitted species that act to destroy stratospheric ozone. To assess the impact of emission strategies in modifying atmospheric ozone there is a need to establish clear links between measured changes in ozone and the processes that cause these changes including changes in climate and changes in emissions. Using long-term global simulations of stratospheric and tropospheric ozone this paper demonstrates the large-scale coupling between extratropical tropospheric and stratospheric ozone variability. We show that an interpretation of interannual tropospheric ozone variability must account for changes in stratosphere-to-troposphere exchange (STE) of ozone.

The tropospheric ozone budget can be summarized in terms of photochemical ozone production and loss, the input of ozone from the stratosphere and the loss of ozone due to surface deposition. The largest terms, the photochemical production and loss of ozone nearly balance each other. Surface ozone deposition and influx from the stratosphere are each larger than the net photochemistry (Stevenson et al., 2006). Changes in the flux of ozone from the stratosphere to the troposphere are buffered by compensating changes in tropospheric photochemical ozone loss and surface deposition (Hess and Zbinden, 2013; Tang et al., 2013; Zeng and Pyle, 2005). Future increases in the exchange of ozone from the stratosphere to troposphere are predicted with impacts on tropospheric ozone (Stevenson et al., 2006; Collins et al., 2003; Zeng and Pyle, 2003; Shindell et al., 2006; Hegglin and Shepherd, 2009).

Except in association with particular events, an overall attribution of tropospheric interannual ozone variability to specific processes has proved difficult. While very longterm ozone increases since the preindustrial are generally attributed to changes in emissions, simulations tend to underestimate the overall ozone increases over the twentieth century (e.g., Lamarque et al., 2005; Mickley et al., 2001) as estimated from the semi-quantitative ozone measurements at the end of the nineteenth century (Marenco et al., 1994; Volz and Kley, 1988). Even on the multidecadal timescales, since the advent of more modern measurement techniques, an attribution of measured tropospheric trends has proved difficult: the extent of the ozone increase since the 1960s as inferred from long-term Northern Hemisphere (NH) measurements has not been simulated (Lamarque et al., 2010; Parrish et al., 2014).
Lin et al. (2014) attribute decadal changes in the interannual Mauna Loa ozone record to shifts in circulation patterns. However, at other locations, ozone exhibits considerable interannual variability on decadal timescales that has not been adequately explained (e.g., Koumoutsaris et al., 2008). In many cases, this ozone variability is not easily ascribed to changes in emissions. For example, changes in emissions do not explain the baseline ozone trends at Mace Head, Ireland (e.g., Hess and Zbinden, 2013; Fiore et al., 2009), measured as strongly positive during the most of the 1990s but since leveling off (Carslaw, 2005; Derwent et al., 2007, 2013; Simmonds et al., 2004). In an analysis of ozone trends over Europe, Wilson et al. (2012) conclude that the impact of European precursor emission reductions was masked by other sources of unknown ozone variability. Analyses by Logan et al. (2012) and Cui et al. (2011) show that the measured ozone increases at Alpine sites over Europe during the 1990s followed by decreases after 2000 are not easily explained by changes in emissions or changes in lower stratospheric ozone. Pozzoli et al. (2011) conclude that changes in meteorology and natural emissions account for $75 \%$ of ozone variability from 1980 to 2005 , largely masking changes in anthropogenic emissions. On decadal timescales, ozone trends can depend sensitively on the exact time period examined (Cui et al., 2011).

While an overall attribution and synthesis of tropospheric ozone variability may be lacking, sources of variability associated with various events have been isolated. The analysis of Leibensperger et al. (2008) shows that decadal and interannual cyclone trends have important impacts on surface ozone variability and trends over the northeastern US, although the analysis of Turner et al. (2013) suggests that cyclones explain less than $10 \%$ of the overall variability of high ozone events over this region. Over the eastern half of the US, changes in interannual temperatures explain between approximately 25 and $50 \%$ of the interannual regional ozone variability in July, although changes in temperature mask other processes. Jaffe et al. (2008) associate interannual variability in ozone across the western US with biomass burning. Interannual variability in ozone due to heat waves (sometimes also associated with changes in emissions) has also been shown to be important (Konovalov et al., 2011; Tressol et al., 2008).

It is well known that stratospheric ozone can be transported into the troposphere (e.g., Danielsen, 1968). Vertical correlations between stratospheric and tropospheric ozone have been analyzed in measurements (Hess and Zbinden, 2013; Tarasick, 2005; Thouret et al., 2006; Ordóñez et al., 2007; Neu et al. 2014) and in model simulations (Terao et al., 2008; Hess and Zbinden, 2013). A number of modeling studies have attributed extratropical $\mathrm{NH}$ tropospheric ozone variability to the El Niño-Southern Oscillation (ENSO) (Zeng and Pyle, 2005; Doherty et al., 2006; Koumoutsaris et al., 2008; Voulgarakis et al., 2011) modulated through STE (Zeng and Pyle, 2005; Voulgarakis et al., 2011). Langford et al. (1998) attribute modulation of middle and upper tropo- 
spheric ozone to ENSO using lidar measurements over Colorado. They suggest that this modulation may induce different long-term decadal ozone trends (between -0.2 and

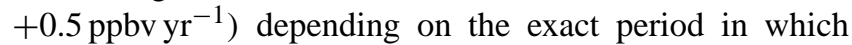
the ozone trend is examined. On the other hand, Hsu and Prather (2009) do not find a relationship between ENSO and STE. Other studies have attributed ozone variability to the North Atlantic Oscillation (NAO) or Arctic Oscillation (AO) (Li, 2002; Creilson et al., 2003, 2005; Lamarque and Hess, 2003; Hess and Lamarque, 2007; Sprenger, 2003; Pausata et al., 2012) with associated changes in STE (Hess and Lamarque, 2007; Sprenger, 2003). Hsu and Prather (2009) show considerable interannual variability in stratospheretroposphere exchange and attribute $20-40 \%$ of this variability to the quasi-biennial oscillation (QBO). Tropospheric ozone decreases have been simulated following the Mt. Pinatubo eruption due to changes in STE (Tang et al., 2013). Hess and Zbinden (2013) argue that, to a significant extent, interannual variability in extratropical tropospheric ozone is due to the variability in ozone transported from the stratosphere. Neu et al. (2014) attribute approximately half of the tropospheric ozone variability to interannual changes in the strength of the stratospheric circulation.

In this paper, we use a synthesis of simulations and measurements to demonstrate the importance of large-scale coupled stratosphere-troposphere modes in determining tropospheric ozone variability from 30 to $90^{\circ} \mathrm{N}$. These results are an extension and expansion of the simulations analyzed in Hess and Zbinden (2013), who show the importance of stratosphere-troposphere exchange in explaining NH extratropical tropospheric ozone variability from 1990 to 2006 . We expand on the work of Hess and Zbinden (2013) by (1) using simulations with good stratospheric resolution and detailed representation of stratospheric chemistry incorporating the impacts of interannual changes in stratospheric aerosol loading and ozone depleting substances (ODS), (2) simulating the chemical coupling between the stratosphere and troposphere over a period of more than 50 years (1953-2005), a period incorporating the rapid growth and then decline of the emissions of ODS, (3) analyzing the extent to which the coupled variability of the lower stratosphere and tropospheric ozone is externally (e.g., by changes in sea-surface temperatures) vs. internally forced, and (4) incorporating further analysis of the large-scale coupled modes linking stratospheric and tropospheric ozone variability.

Distinct from Hess and Zbinden (2013), we use a simulation that only simulates basic tropospheric $\mathrm{NO}_{\mathrm{x}}-\mathrm{CH}_{4}$ chemistry. By examining the importance of stratospherictropospheric coupling using a basic set of tropospheric chemistry reactions, the importance of more complex chemistry in determining tropospheric ozone variability can be better understood. It is expected that the introduction of additional hydrocarbon chemistry as well as episodic emission variability (e.g., biomass burning) will introduce additional modes of variability not captured here. In addition, more complex chemistry may possibly dampen the basic modes of ozone variability described below. However, despite the simplicity in the tropospheric chemistry, these simulations match the observed ozone variability to a large extent. Thus, we view the modes of ozone variability captured here as base-state modes that may be perturbed by more complex chemistry but are fundamental to the coupled troposphere-stratosphere chemical system.

The model description and the description of the data analyzed are given in Sect. 2. An evaluation of the simulations is given in Sect. 3. Section 4 analyzes the ozone variability. Discussion and conclusions are given in Sect. 5.

\section{Methodology}

\subsection{Model description}

The Whole Atmosphere Community Climate Model, Version 3.5 (WACCM3.5) is a comprehensive numerical model simulating the dynamics and chemistry of the atmosphere, spanning the range of altitude from the Earth's surface to the lower thermosphere. Four long-term ensemble free running (FR) WACCM3.5 simulations for the period from 1953 to 2005 are generated by initializing the model with different initial conditions. The analysis of these simulations focuses on the tropospheric and lower stratospheric ozone distribution from 30 to $90^{\circ} \mathrm{N}$.

WACCM3.5 is a fully interactive model, wherein the radiatively active gases $\left(\mathrm{CO}_{2}, \mathrm{H}_{2} \mathrm{O}, \mathrm{N}_{2} \mathrm{O}, \mathrm{CH}_{4}, \mathrm{CFC}-11\right.$, CFC$12, \mathrm{NO}, \mathrm{O}_{3}$ ) affect heating and cooling rates and therefore dynamics (Sassi et al., 2005). WACCM3.5 is based on the software framework of the Community Atmospheric Model (CAM). WACCM3.5, is a superset of CAM version 3 (CAM3), and includes all of the physical parameterizations of that model. A finite volume dynamical core (Lin, 2004), which is an option in CAM3, is used exclusively in WACCM3.5. This numerical method calculates explicitly the mass fluxes in and out of a given model grid cell, thus ensuring mass conservation.

The governing equations, physical parameterizations and numerical algorithms used in CAM3 are documented by Collins et al. (2006); only the gravity wave drag and vertical diffusion parameterizations are modified for WACCM3.5. In addition, WACCM3.5 incorporates a detailed neutral chemistry model for the middle atmosphere, including heating due to chemical reactions; a model of ion chemistry in the mesosphere/lower thermosphere (M/LT); ion drag and auroral processes; and parameterizations of short wave heating at extreme ultraviolet (EUV) wavelengths and infrared transfer under non-local thermodynamic equilibrium (NLTE) conditions. Processes and parameterizations that are unique to WACCM3.5 are discussed in Garcia et al. (2007); for other details, the reader is referred to the papers of Collins et al. (2006). 


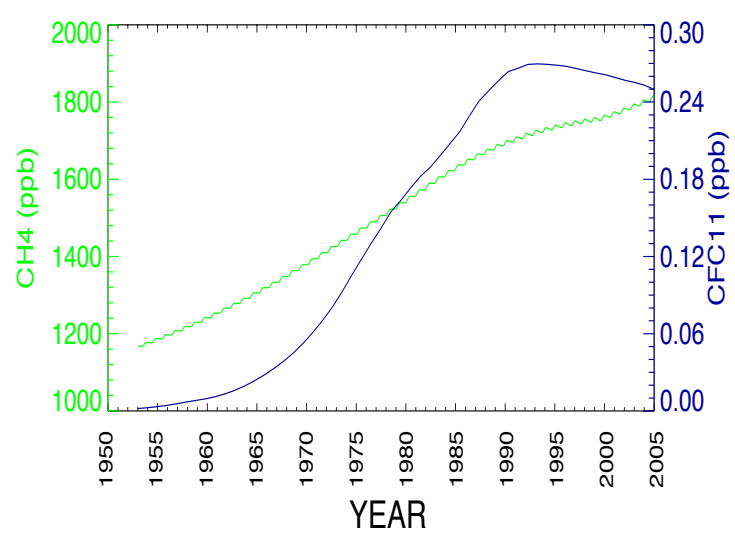

Figure 1. Model forcings. Concentrations of $\mathrm{CH}_{4}$ (green, left axis) and CFC-11 (blue, right axis) globally area-averaged at the lower boundary and used to force the WACCM3.5 simulations.

The chemistry module in WACCM3.5 is based on the Model for OZone And Related chemical Tracers version 3 (MOZART3) (Kinnison et al., 2007). The species included within this mechanism are contained within the $\mathrm{O}_{\mathrm{x}}, \mathrm{NO}_{\mathrm{x}}$, $\mathrm{HO}_{\mathrm{x}}, \mathrm{ClO}_{\mathrm{x}}$, and $\mathrm{BrO}_{\mathrm{x}}$ chemical families, along with $\mathrm{CH}_{4}$ and its degradation products (a total of 59 species and 217 gas-phase chemical reactions). This chemical mechanism includes 10 long-lived organic halogens (i.e., $\mathrm{CH}_{3} \mathrm{Cl}, \mathrm{CFC}-11$, CFC-12, CFC-113, HCFC-22, $\mathrm{CCl}_{4}, \mathrm{CH}_{3} \mathrm{CCl}_{3}$, halon-1211, halon-1301, and $\mathrm{CH}_{3} \mathrm{Br}$ ). Rate constants are based on Sander et al. (2006). In addition, there are 17 heterogeneous reactions on three aerosol types: nitric acid trihydrate (NAT), supercooled ternary solution (STS), and water ice. A detailed description of the chemical approach can be found in Kinnison et al. (2007).

For this work, the Chemistry Climate Model Validation Activity for the SPARC version 2 (CCMVal2) REF1 scenario was used (see Eyring et al., 2008). This scenario includes the observed time-dependent evolution of greenhouse gases (GHGs), ODSs, sea-surface temperatures and sea ice concentrations (SSTs/SICs), stratospheric sulfate surface area densities (SADs), 11-year solar cycle variability, which includes spectrally resolved solar irradiances, and the quasibiennial oscillation (QBO), by relaxing to observed tropical winds. Surface emissions of $\mathrm{CO}, \mathrm{NO}_{\mathrm{x}}$, and formaldehyde are included, but the emission trends are not simulated. The emissions are set to present-day conditions. This version of WACCM was extensively evaluated in the SPARC Report on the Evaluation of Chemistry-Climate Models (SPARCCCMVal, 2010).

Figure 1 gives the change in boundary conditions for $\mathrm{CH}_{4}$ and CFC-11. CFC-11 peaks in 1992 (World Meteorological Organization (WMO), 2007) and then begins slowly to decline. Methane shows a nonlinear growth rate, with evidence of a flattening trend beginning in the early 1990s (e.g., Dlugokencky et al., 2011).

\subsection{Data}

The WACCM simulation is evaluated at $150,500 \mathrm{hPa}$, and a number of surface stations between 30 and $90^{\circ} \mathrm{N}$ including elevated alpine sites. Long-term monitoring sites and ozonesonde records are used for model evaluation (see Table 1).

Ozonesonde data are obtained from the World Ozone and Ultraviolet Radiation Data Centre (WOUDC). The methodology for filtering the measurements is similar to that described in Hess and Zbinden (2013), except that we combined different measurement techniques together so as to extend the measurement records as far back as possible. As in Hess and Zbinden (2013), we aggregated the 150 and $500 \mathrm{hPa}$ ozonesonde data into geographical regions. This acts to isolate the larger-scale interannual variability and increases the sampling frequency. We use geographical regions located between 30 and $90^{\circ} \mathrm{N}$ where at least two longterm independent ozonesonde measurements are available: Canada, central Europe, Japan and northern Europe (see Table 1). Here, we simply aggregate the regional ozone measurements by averaging the individual measurements within each region. Hess and Zbinden (2013) aggregated the measurements by averaging their relative variability, but the two methodologies produce very similar results.

At the surface, we include many of the same long-term measurement sites between 30 and $90^{\circ} \mathrm{N}$ as used in Lamarque et al. (2010) (see Table 1). We have combined the Zugspitze alpine measurements with those of the neighboring Jungfraujoch measurement site. We have omitted measurement sites immediately downwind of Asian or US emissions (Mt. Happo, Japan; Bermuda; Sable Island, Novia Scotia) as our simulations are best suited to sampling background air as we include no changes in surface emissions. We have, however, included the Lassen National Park site in the western US, even though this site likely registers impacts of increasing Asian emissions (e.g., Cooper et al., 2010; Parrish et al., 2012). This site is subject to significant interannual variability not explained by changes in Asian emissions (see Fig. 5). We have also omitted the Barrow site due to the influence of Arctic depletion events on the Barrow record (e.g., Oltmans et al., 2012). However, we have included the Arkona site as it has very long-term surface measurements extending back to 1957.

For each measurement site, or measurement region, monthly ozone deviations are calculated as deviations from the monthly averaged ozone distribution from January 1990 to December 2004 (or as much as that period for which data is available). The monthly deviations are averaged using 12 month smoothing. 
Table 1. Measurement sites used in this paper.

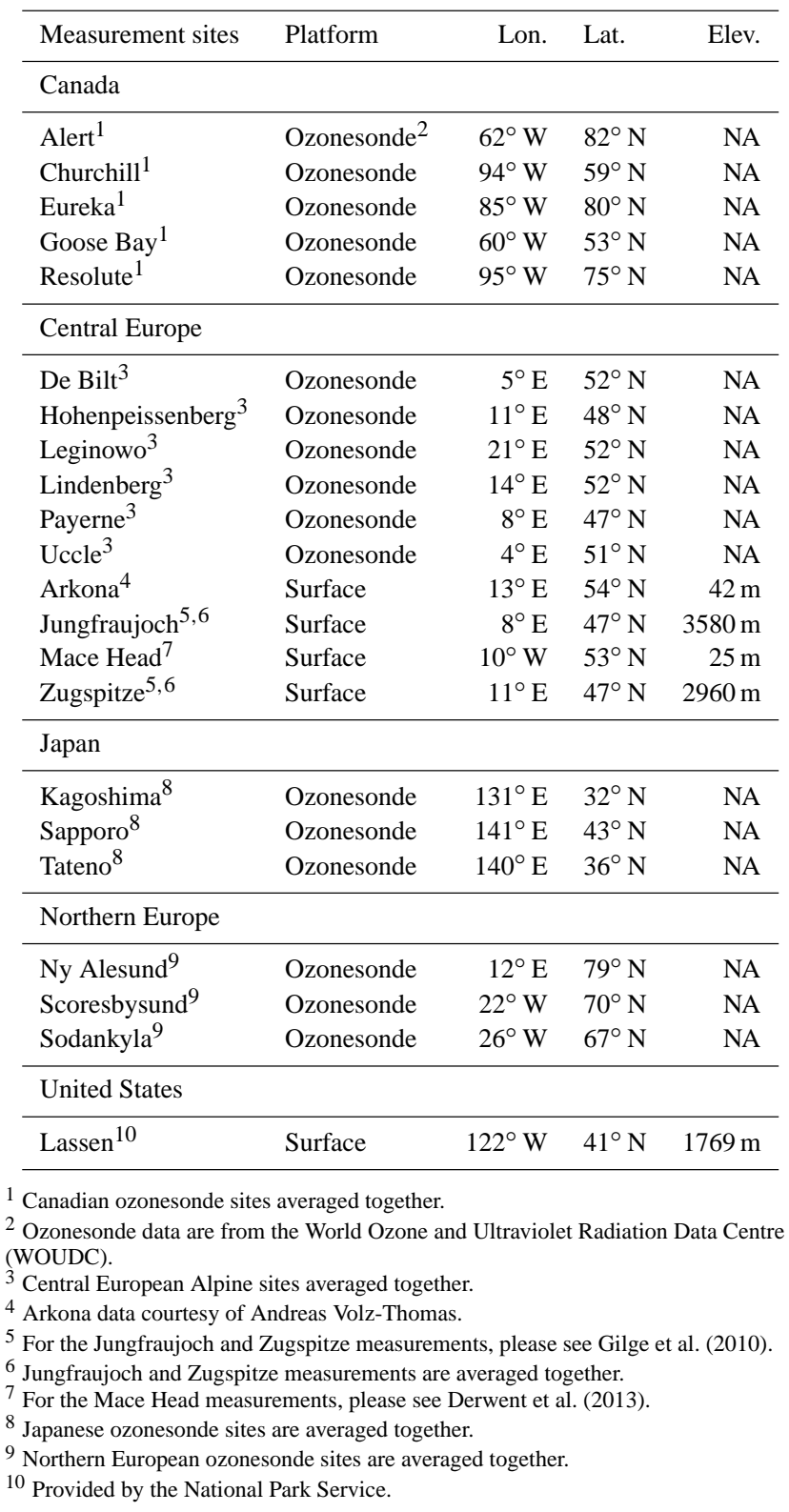

\section{Model evaluation}

\subsection{Simulation overview}

Ozone for the four ensemble simulations averaged from 30 to $90^{\circ} \mathrm{N}$ is shown in Fig. 2 at $150,500 \mathrm{hPa}$ and the surface. At each level, for each of the ensemble simulations, ozone follows a similar long-term trajectory (Fig. 2). At $150 \mathrm{hPa}$, this trajectory is at least partially governed by the ODS forcing common to all ensemble members. At $150 \mathrm{hPa}$, over the longterm, ozone levels remain nearly constant until 1970, but thereafter decrease and reach a minimum between 1991 and 1994 in association with the Mt. Pinatubo eruption (Fig. 2a).
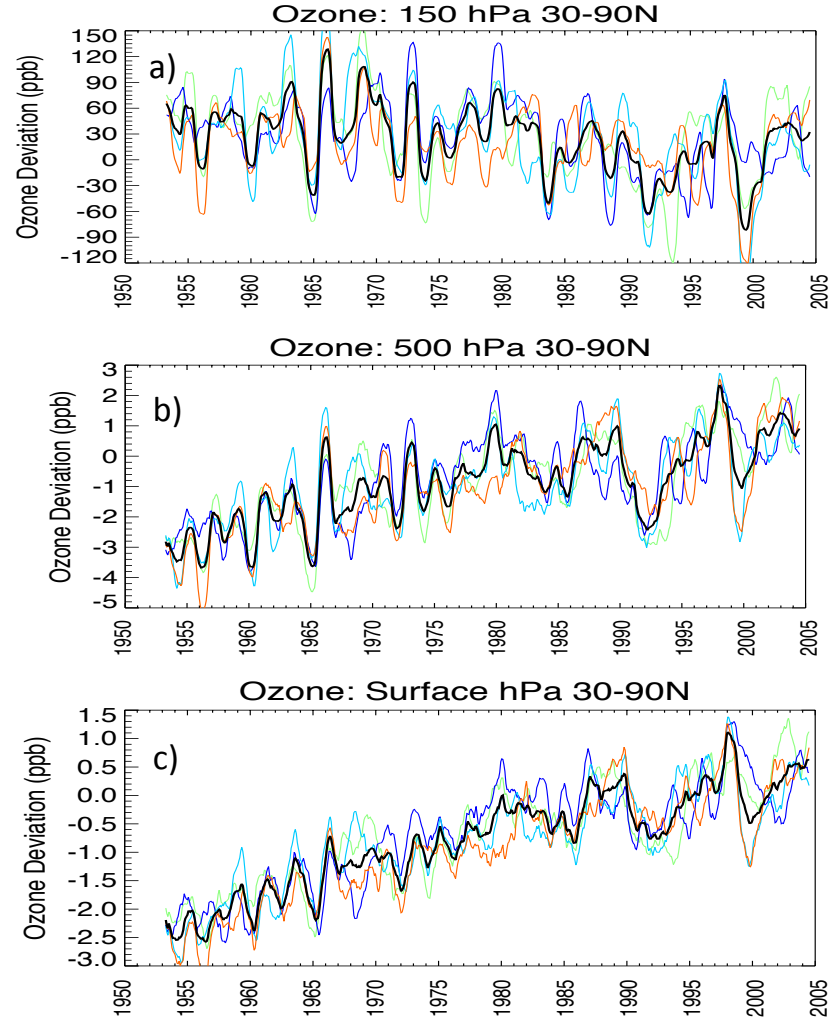

Figure 2. Ozone deviations (ppb) averaged from 30 to $90^{\circ} \mathrm{N}$ for each WACCM ensemble member (colored) and the deviation averaged over all ensemble members (black) at (a) $150 \mathrm{hPa}$, (b) $500 \mathrm{hPa}$ and (c) the surface. Monthly ozone deviations are smoothed over 12 months. Deviations are from ozone averaged 1 January 1990-31 December 1994.

Note that even though all ensemble members simulate ozone loss associated with Mt. Pinatubo, the timing of this loss is partially governed by the internal model variability. In all simulations $150 \mathrm{hPa}$ ozone partially recovers following the Mt. Pinatubo period. At $500 \mathrm{hPa}$ and the surface, all simulations show a long-term ozone increase throughout the pe$\operatorname{riod}($ Fig. 2b, c). This increase can be largely attributed to the long-term methane forcing (Fig. 1). The long-term growth in ozone is approximately linear until 1980 when it begins to flatten.

On shorter timescales each of the ensemble simulations follows its own path relative to the mean long-term trend. However, there are some notable periods where all ensemble members show similar behavior with a coincident ozone maximum or minimum across all model levels (e.g., 1965, 1967, 1972, 1973, 1998); during other periods the short timescale behavior of the individual ensemble members appear unrelated (e.g., 1968-1971, 1977-1983, 1993-1997). 


\subsection{Evaluation}

In the sections below the model behavior depicted in Fig. 2 is examined in detail. In this section the model measurement evaluation is given at selected sites from $150 \mathrm{hPa}$ to the surface (see Table 1). The model-measurement evaluation is shown in Figs. 3-6 and is summarized in Table 2. A comparison of the area averaged ozone evolution (Fig. 2) and that at the individual ozone sites reveals broad similarities. The similarity between the ozone evolution at various measurement sites and the overall hemispheric evolution was pointed out in Hess and Zbinden (2013). This is further examined in Sect. 4, where we examine coupled stratospherictropospheric modes of ozone variability.

The model-measurement correlations (Table 2) are between 12-month smoothed data sets and use detrended data so as not to introduce positive correlations simply through a simulation of long-term trends. In the stratosphere ozone is simply detrended against time; in the troposphere ozone is detrended against methane as changes in methane largely drive the simulated ozone increases (see Sect. 4). We note it is difficult to unambiguously separate out the shorter-term interannual variations from the longer-term trends, particularly when the long-term trends have a comparable magnitude to the interannual variations. We believe this is particularly problematic in the analysis of some of the tropospheric measurements with large ozone increases (e.g., at Lassen). The simulated ozone is obtained from monthly averaged model output at all measurement stations within a region. No attempt is made to duplicate the temporal sampling of the measurements at each measurement site. The modelmeasurement correlation is broken into two periods: prior to 1990 and subsequent to 1990 . The larger number of measurement sites and the increase in measurement accuracy make comparisons after 1990 particularly valuable. The simulated and measured records are only correlated when the records extend for periods of greater than 5 years. Shorter-term model-measurement comparisons (1991-1995) are made in Tang et al. (2013) using a similar formulation of WACCM as used here, but with full hydrocarbon chemistry in the troposphere. Tang et al. (2013) also compare the measurements against simulations using a specified dynamics formulation of WACCM, where WACCM is nudged to analyzed winds. The more tropospherically configured model, the Community Atmospheric Model with chemistry (CAMchem) (Lamarque et al., 2012) has been compared against a similar set of measurements in Hess and Zbinden (2013) and Tang et al. (2013).

Not until the 1960s do ozonesonde measurements become available for the Canadian, central European and Japanese sites (Table 2). Data are not available for the northern European region until the late 1980s. Figures 3-4 give the observational record for each ozonesonde site within each region and document the changes in the type of ozonesonde used at each site. The accuracy of the regionally averaged ozone records likely changes with time as the number of stations and measurement techniques change (e.g., from BrewerMast (BM) ozonesondes to electrochemical concentration cells (ECC)). The standard deviation between the regional measurements shown at the bottom of each figure gives an indication of temporal changes in the regional consistency of the measurements.

\subsection{1 $150 \mathrm{hPa}$ evaluation}

At $150 \mathrm{hPa}$, simulated ozone remains fairly flat at the analyzed sites (e.g., Fig. 3) until the late 1960s, when the earliest measurements become available. Coincident with the increase in the concentrations of ODS (e.g., see Fig. 1), simulated ozone decreases from the 1970s until the early 1990s over the four regions examined (Canada, central Europe, Japan and northern Europe). Measured decreases during this period are particularly notable over the Canadian and central European regions. While the standard deviation between the regional measurement sites is comparatively large prior to 1990 over the Canadian region (Fig. 3), the standard deviation is still smaller than the overall long-term trend (19701990). The early record over Japan is somewhat noisier, but also suggests long-term ozone decreases during this period (Fig. 3). The negative ozone deviations at $150 \mathrm{hPa}$ in the early 1990s can be attributed to Mt. Pinatubo, which resulted in significant ozone depletion in the northern mid-latitudes beginning in 1991 and lasting through 1995 (e.g., Tang et al., 2013). Since the early 1990 s the $150 \mathrm{hPa}$ ozone at the evaluated sites has recovered to some extent.

In addition to the long-term trends, the simulations and measurements also exhibit considerable shorter-term interannual variability at $150 \mathrm{hPa}$. For the period beginning in 1990, the model and measured records are significantly correlated over Canada (at the $99 \%$ level) and northern Europe (at the $98 \%$ level) (Fig. 3 and Table 2). For example, after 1990, both measurements and simulated ozone over Canada and northern Europe have an ozone minimum during the Mt. Pinatubo period, a maximum in 1998-1999 and 2002-2003 and pronounced ozone minima near 2000. These features can also be seen in the central European record (Fig. 3). Prior to 1990, the detrended simulated and measured variability are significantly correlated over Canada and central Europe (Table 2) at $150 \mathrm{hPa}$. Over Canada, the standard deviation between the individual station measurements is relatively large prior to 1990, suggesting caution in interpreting the early measurements. Nevertheless, the peak in the Canadian measurements in 1970 and 1973 and the broad peak from 1977 to 1983 correspond to similar features in the central European measurements, suggesting that these features may be real. The simulation and measurements are not significantly correlated over Japan. Hess and Zbinden (2013) found the measurements from the individual stations over Japan are not temporally coherent at $150 \mathrm{hPa}$. This is evident from the rather high standard deviation between the ozonesonde sta- 
Table 2. Comparison between ensemble mean simulated and measured ozone over various regions or sites.

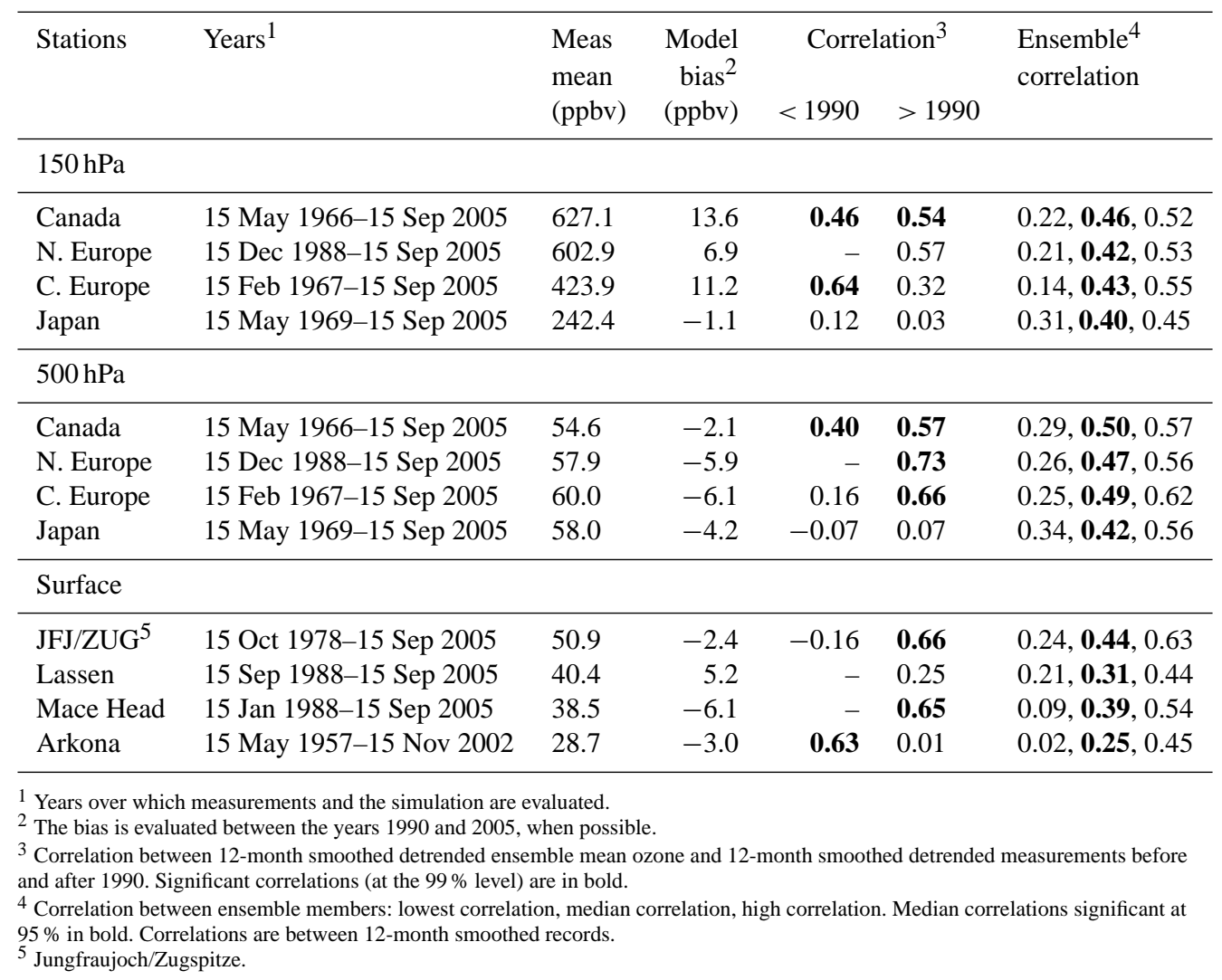

tions (Fig. 3). In fact, we have not been able to simulate the ozone record over Japan either prior to 1990 or subsequent to 1990 at either $150 \mathrm{hPa}$ or at $500 \mathrm{hPa}$ in the current simulations.

\subsection{2 $500 \mathrm{hPa}$ evaluation}

While the $150 \mathrm{hPa}$ simulated and measured standard deviation between regional sites is similar in the model and measurements (Fig. 3), at $500 \mathrm{hPa}$, the measured standard deviation is much larger than that simulated (Fig. 4). This suggests a comparative degradation in the measurement accuracy at $500 \mathrm{hPa}$ compared to $150 \mathrm{hPa}$ and/or geographical variability not simulated. In particular, the decrease in the number of regional measurement sites during the early periods may accentuate the geographic differences in the measured ozone, particularly in the troposphere, where the spatial scale of variability is likely to be smaller than in the stratosphere. Over Europe in particular, the measured standard deviation increases significantly prior to 1990 . The analysis of Logan et al. (2012) shows that the ozonesonde data have only been coherent over Europe since 1998. Hess and Zbinden (2013) also noted discrepancies in the European data during the 1990s.

Over the long-term significant ozone increases are both simulated and measured over the $500 \mathrm{hPa}$ tropospheric sites. In the simulation these increases can be attributed to the long-term increases in methane (Fig. 1); in the measurements, the emissions of many other ozone precursors also increased over this time period. Prior to the early 1980s simulated ozone significantly over predicts the tropospheric measurements, except over Japan. We note that even simulations using complex mechanisms for tropospheric photochemistry and time varying emission inventories have not been able to capture the measured ozone increases since 1980 (Lamarque et al., 2010; Parrish et al., 2014). The Canadian sites show a rapid ozone increase until 1980, while the central European sites show that this increase lasts until the middle to late 1980s, consistent with European Alpine sites (see Fig. 5). However, whereas the Canadian and alpine sites suggest that ozone in the mid-1980s was comparable to the concentrations after 2000, the central European ozonesondes show elevated concentrations during this earlier period. The measured high ozone concentrations over central Europe at $500 \mathrm{hPa}$ are not simulated.

Except over Japan, the model and measurements are significantly correlated after 1990 at $500 \mathrm{hPa}$ over the evaluated regions (Table 2). During the early 1990s, the eruption of Mt. Pinatubo resulted in anomalously low tropospheric ozone (Tang et al., 2013) clearly evident over the central and northern European and Canadian regions in both the simulations and measurements (Fig. 4). The elevated ozone 

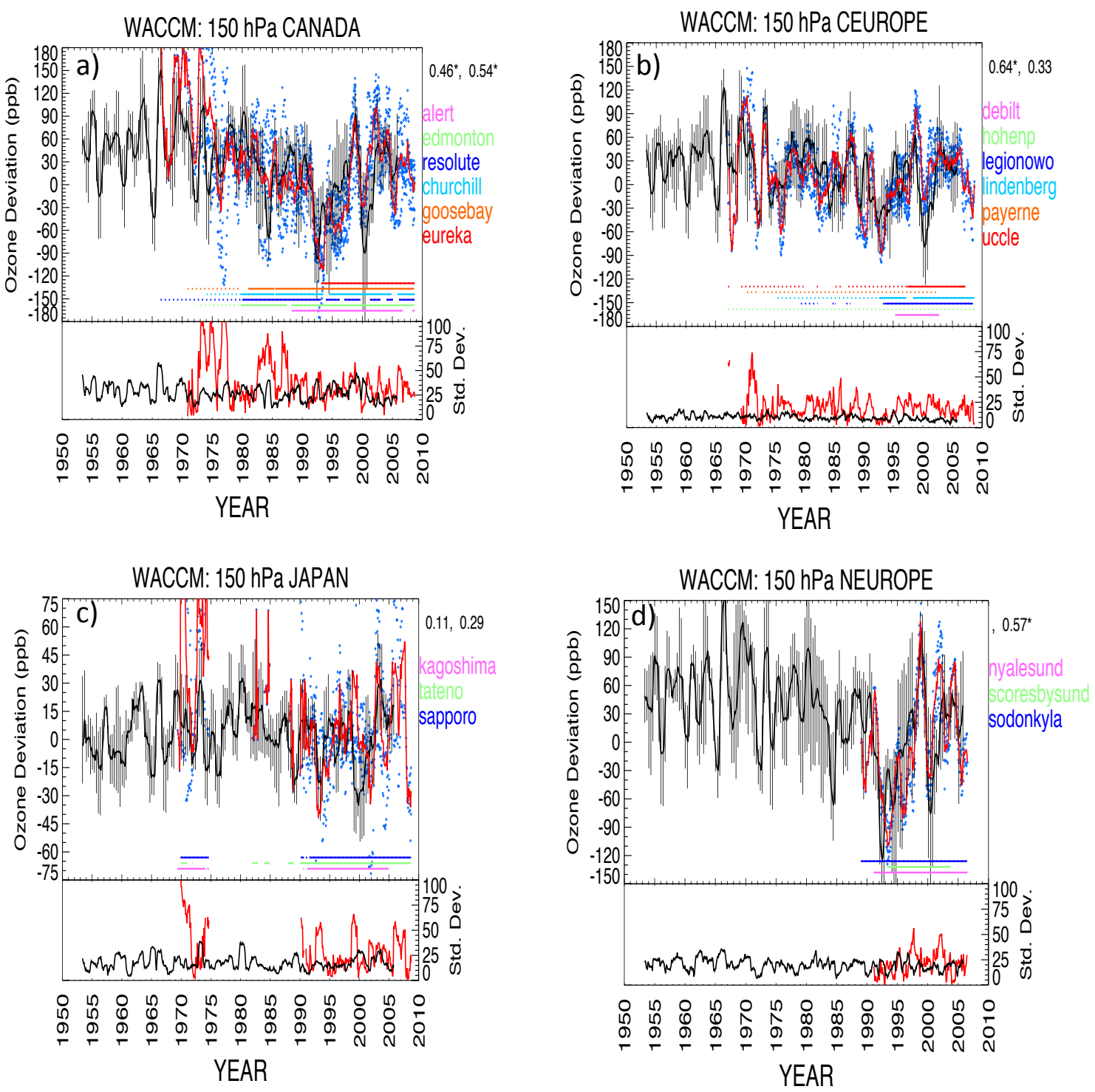

Figure 3. Simulated and measured ozone deviations (ppb) at $150 \mathrm{hPa}$ averaged over the (a) Canadian ozonesonde sites, (b) the central European ozonesonde sites, (c) the Japanese ozonesonde sites and (d) the northern European ozonesonde sites. The simulated ensemble average is given as the bold black line, the thin black lines bracket the maximum and minimum ensemble ozone deviation, the measured average is given as the red line, the blue dots give the measured ozone deviation for each site comprising the regional average. Colored bars indicate when each measurement site (color coded as indicated on right) made sufficient measurements to calculate an annual ozone concentration: solid lines indicate an ECC or KC measurement and dotted lines a Brewer-Mast ozonesonde measurement. The black and red lines at the bottom give the simulated (black) and measured (red) standard deviation of ozone (ppb) calculated across all sites within each region. Numbers in the upper right give the model-measurement correlation of the average ozone within each region prior to 1990 (left) and after 1990 (right). Correlations use detrended data. Significant correlations at the $95 \%$ level are starred. Monthly ozone deviations are smoothed over 12 months. Deviations are from ozone averaged 1 January 1990-31 December 1994. The simulated ozone record uses monthly averaged output at each measurement site throughout the simulation with no attempt to duplicate the actual temporal sampling of the measurements.

in 1998-1999 evident in the measurements and simulations (also see Thouret et al., 2006; Zbinden et al., 2006) has been attributed to ENSO (Koumoutsaris et al., 2008; Voulgarakis et al., 2011) and has been associated with increases in STE (Voulgarakis et al., 2011; Hess and Zbinden 2013).
The model and measurements are also significantly correlated over the Canadian ozonesonde sites prior to 1990. 


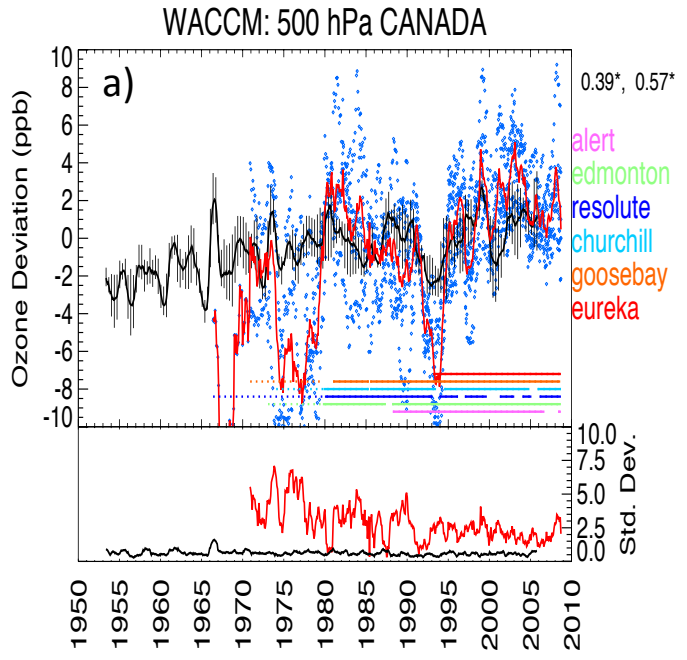

YEAR

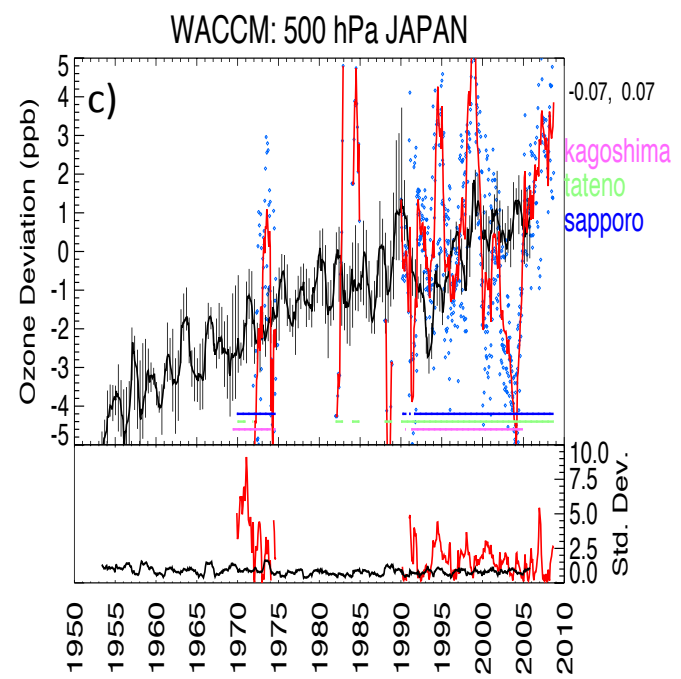

YEAR

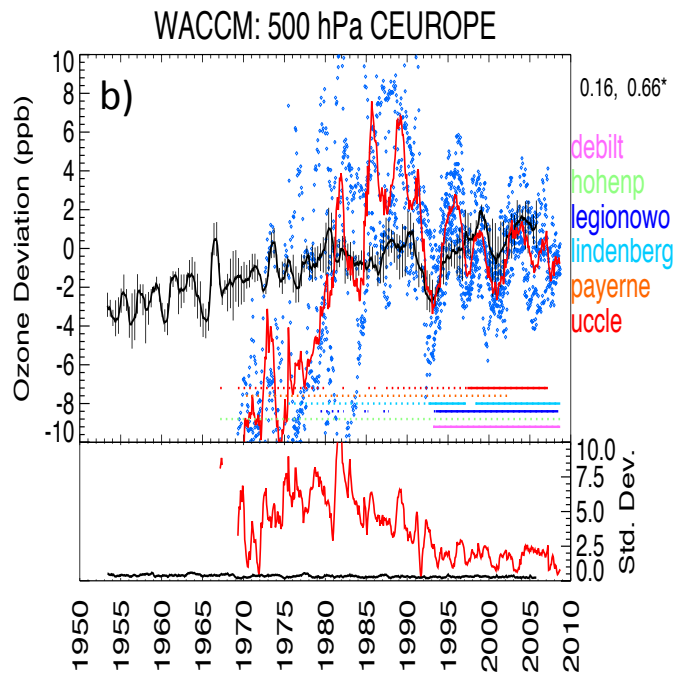

YEAR

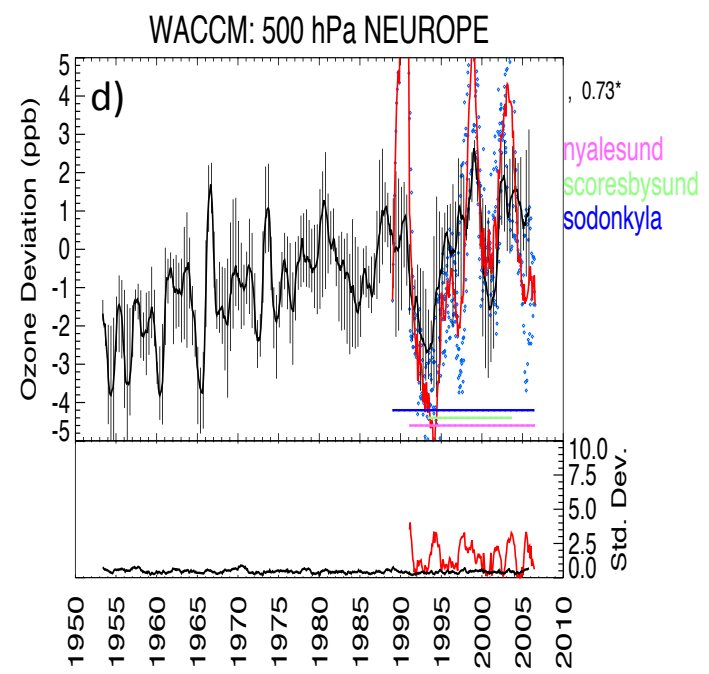

YEAR

Figure 4. As in Fig. 3 but at $500 \mathrm{hPa}$ averaged over (a) the Canadian ozonesonde sites, (b) the central 500 hPa European ozonesonde sites, (c) the Japanese ozonesonde sites and (d) the northern European ozonesonde sites.

\subsubsection{Surface evaluation}

As at $500 \mathrm{hPa}$, the European mountain sites (Fig. 5a), the Mt. Lassen site in California (Fig. 5b), the Mace Head site in western Europe (Fig. 6b) and the Arkona site in continental Europe (Fig. 6a) all exhibit an ozone minimum in the measurements and simulations near 1993-1994 (although not very pronounced in the Mace Head measurements) and an ozone maximum near 1998-1999. The simulations and measurements are significantly correlated at the European mountain sites after 1990 (Fig. 5a) and at Mace Head (Fig. 6b), but not at Lassen (Fig. 5b) or Arkona (Fig. 6a). The ozone record at Lassen is particularly susceptible to the large increase in Asian ozone precursor emissions (e.g., Cooper et al., 2010; Parrish et al., 2012), increases not included in the simulation. Interannual variability in the transport of ozone produced from these Asian emissions as well as difficulties in unambiguously removing the ozone trend at Lassen may contribute to the low model-measurement correlation at that site. The model simulations, assuming no increases in emissions capture much of the measured variability and ozone change that occurred since 1990 at these sites. The Arkona site is situated over continental Europe in a region immediately impacted by European emissions. At this site, the simulations dramatically overestimate the measured concentrations prior to 1990 (Fig. 6a), and do not capture the ozone variability subsequent to 1990 . 

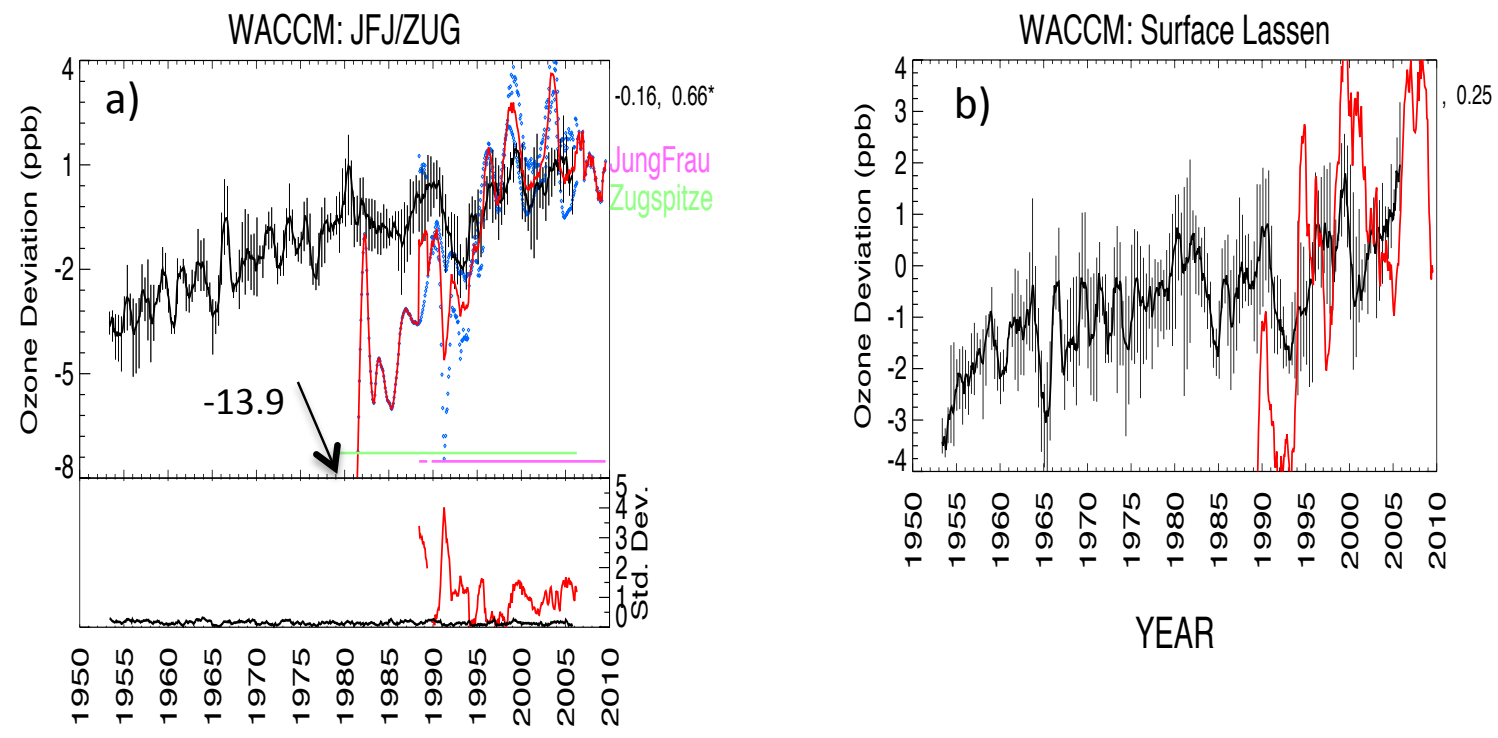

YEAR

Figure 5. As in Fig. 3 but for the surface simulated and measured ozone deviations (ppb): (a) averaged for the Jungfraujoch and Zugspitze sites; (b) the Lassen site. The bottom bars in (a) indicate the years for which an annually averaged measurement was available at the Jungfraujoch and Zugspitze sites.

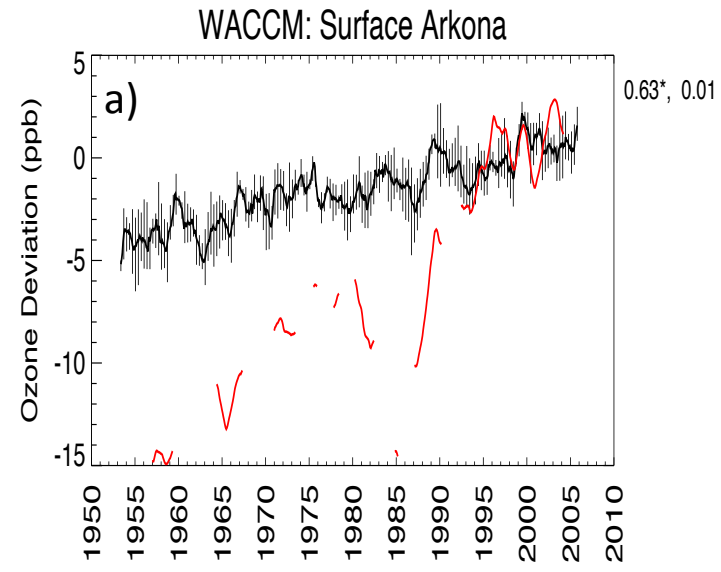

YEAR

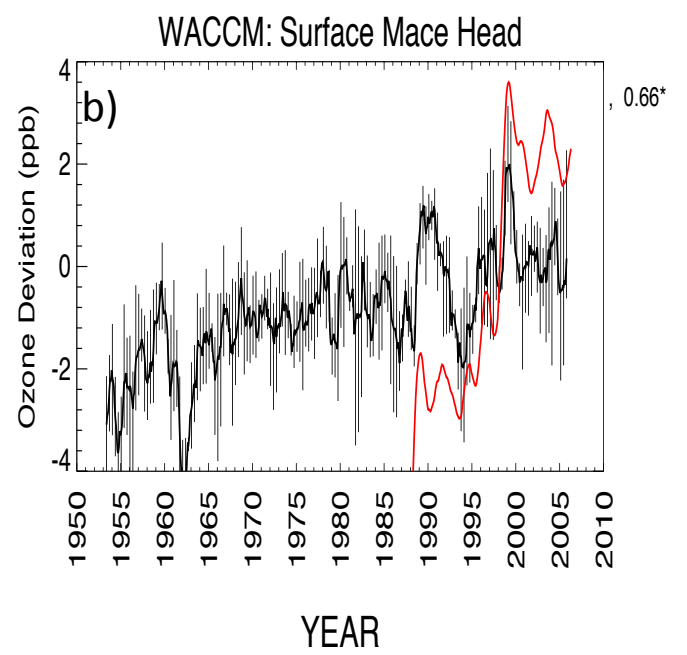

Figure 6. As in Fig. 3 but for (a) the surface measurements at Arkona and (b) the surface measurements at Mace Head.

\section{Long-term tropospheric ozone variability}

\subsection{Forced vs. unforced variability}

Over the long-term the trends in the simulated ozone are driven by the trends in the concentrations of ODSs and methane and the solar cycle. Short-term external forcing can be attributed to forcing by sea-surface temperature, volcanoes and the QBO. To the extent that the ozone record is driven by internal model dynamics vs. interannually varying external forcing, we would expect the ozone records from the different ensemble members to be uncorrelated with each other and uncorrelated with the measurements. Given a perfect model (and perfect measurements), the correlation between simulations and measurements should give an indication of the importance of external forcing to the simulations. The positive and significant model-measurement correlations at various sites, particularly for the period after 1990 (see Table 2), in simulations in which model dynamics 
is internally calculated, emphasize the importance of forced variability in driving the ozone variations.

The correlation between ensemble members also provides an indication of the extent to which the model is externally forced. The average median detrended correlation between the different simulations at all sites is highly significant (see Table 2), suggesting that the role of external forcing is significant. These correlations tend to be somewhat lower at the surface. These lower surface correlations likely reflect the shorter lifetime of ozone near the surface and thus an increased importance of local and regional processes. The correlations are lowest at Arkona, suggesting a decreased role for forced variability in association with high surface ozone precursor emissions. The mean ensemble correlations suggest that between 6 and $19 \%$ of the ozone variability at the surface measurement sites can be explained by external forcing and that between 16 and $25 \%$ of the variability is forced at 500 and $150 \mathrm{hPa}$. The ensemble correlations over the course of the simulation are generally less than the model-measurement correlations, but the high modelmeasurement correlations generally occur after 1990, when the external forcing due to Mt. Pinatubo and the 1998-1999 El Niño is particularly strong.

\subsection{Response of tropospheric ozone to changes in methane and stratospheric ozone flux}

In addition to photochemical changes in the tropospheric ozone budget, tropospheric ozone is modulated by the flux of ozone from the stratosphere (e.g., Stevenson et al., 2006). The vertical component of the zonally averaged vertical residual velocity $\left(\overline{w^{*}}\right)$ and the ozone flux across $100 \mathrm{hPa}$ averaged from 30 to $90^{\circ} \mathrm{N}$ is shown in Fig. 7 for each ensemble member. The vertical component of the residual circulation $\left(\overline{w^{*}}\right)$ approximates the vertical transport circulation (Andrews et al., 1987) and serves as a measure of the strength of the overturning Brewer and Dobson circulation. The averaged downward residual velocity at $100 \mathrm{hPa}$ increases from 1953 to 2005 (Fig. 7a) in all the ensemble simulations. We note that, during some years, $\overline{w^{*}}$ in each of the ensemble simulations is similar, while during other years, $\overline{w^{*}}$ appears rather unrelated between the different ensemble members. On average, the residual circulation increases downward by approximately $15 \%$ over the course of the simulation. This increase in the residual circulation is a robust feature of chemistry climate model simulations (Butchart et al., 2006, 2010; Eyring et al., 2010; SPARC-CCMVal, 2010; Oman et al., 2010). The simulated increase in the downwards component of $\left(\overline{w^{*}}\right)$ averaged from 30 to $90^{\circ} \mathrm{N}$ (Fig. 7a) is due to both an increase in the strength of the downward component of $\left(\overline{w^{*}}\right)$ and an increase in the area in which $\left(\overline{w^{*}}\right)$ is downwards. The latter is consistent with a narrowing of the upwelling branch of the Brewer-Dobson circulation in response to climate change ( $\mathrm{Li}$ et al., 2010; Hardiman et al.,
2014). A cubic fit (Fig. 7a) suggests that this increase in $\overline{w^{*}}$ is not exactly linear, but has increased since 1990 .

The $100 \mathrm{hPa}$ ozone flux averaged from 30 to $90^{\circ} \mathrm{N}$ is calculated by multiplying the residual vertical velocity by the ozone concentration. Gettleman et al. (1997) suggest that the flux of ozone across this level serves as a good proxy for the flux of ozone from the stratosphere to the troposphere. While diagnostics of the STE of ozone across the tropopause would be preferable, they could not be estimated precisely from the monthly averaged model output fields saved from these simulations. The ozone flux from 30 to $90^{\circ} \mathrm{N}$ averages $352 \mathrm{Tg} \mathrm{yr}^{-1}$, while the global flux averages $513 \mathrm{Tg} \mathrm{yr}^{-1}$. The global flux is similar to the estimate in Hsu and Prather (2009). In contrast to the fitted increase in the downwards-residual velocity (Fig. 7a), the change in the ozone flux has not been monotonic (Fig. 7b). The cubic fit to the ozone flux reaches a maximum in the 1960s as the residual circulation increases in strength and stratospheric ozone remains fairly constant; following this period, the ozone flux decreases until the early 1990s (corresponding to the time of the Mt. Pinatubo eruption) as stratospheric ozone decreases; following Mt. Pinatubo, the ozone flux increases again until the end of the model simulation. On average, the ozone flux has increased by $8 \%$ from 1953 to 2005, about half the rate of the increase in the residual circulation. Hegglin and Shepherd (2009) also show that the ozone flux is modulated by ozone depletion in the $\mathrm{NH}$, but suggest no longterm decrease in the flux, with the smallest fluxes occurring near 2000. We note that the simulations described in Hegglin and Shepherd (2009) include no forcing due to volcanoes. In the future, predicted stratospheric ozone recovery and predicted increases in the strength of the residual circulation are expected to lead to further increases in the stratosphere-totroposphere exchange of ozone (e.g., Hegglin and Shepherd, 2009).

The long-term impact of changes in the stratospheric ozone flux on tropospheric ozone is clearly seen in Fig. 8. Here we examine the evolution of normalized ozone against tropospheric methane. Ozone is normalized by dividing the ozone record by the average ozone concentration from 1980 to 1985: Parrish et al. (2014) found that normalizing ozone helped reduce the ozone record at different measurement sites to a common curve. The exact date used for normalization is arbitrary. We found that the data displayed nicely when we used the ozone average from 1980 to 1985 to normalize the ozone record. The simulated record of normalized ozone plotted against globally averaged methane reduces the ozone record to a set of similar curves at various tropospheric measurement sites (Fig. 8a). We find that a cubic fit of ozone against tropospheric methane captures some of the subtleties of the long-term record better than a quadratic fit. Discussion of various polynomial fits is given in Parrish et al. (2014). Here we only display those locations (see Table 1) where the ozone measurements extend to the early 1980s. 

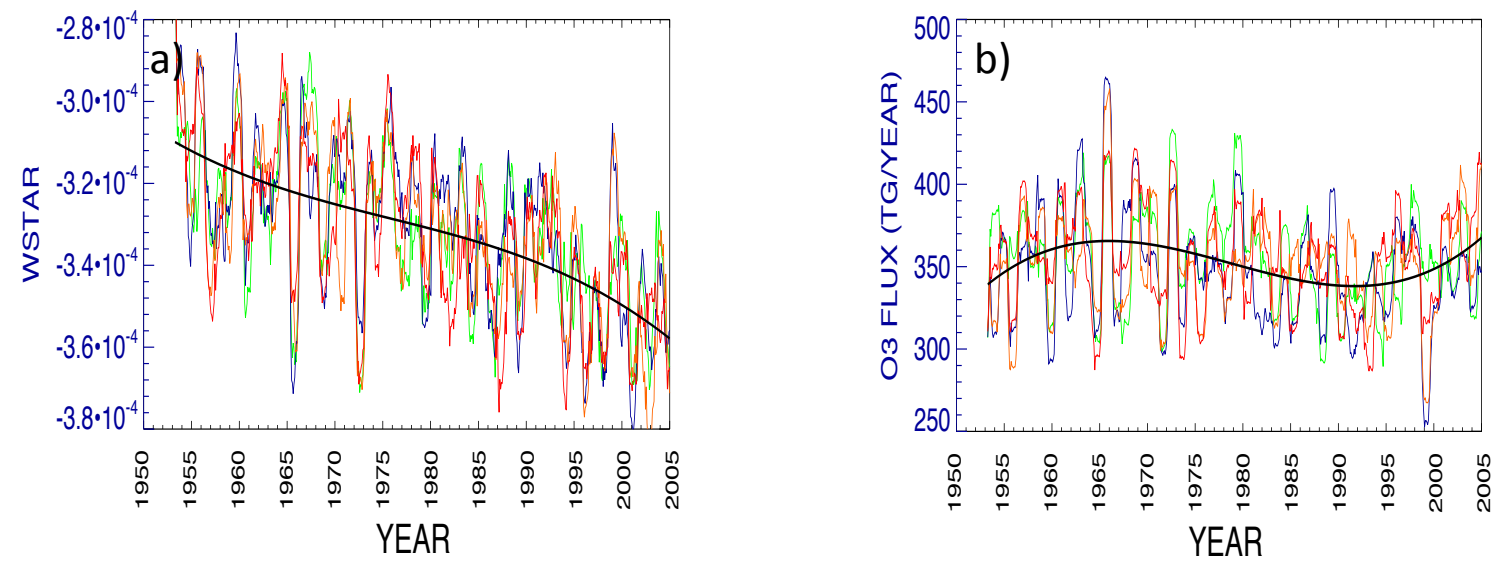

Figure 7. The (a) vertical residual velocity $\left(\overline{w^{*}}, \mathrm{~m} \mathrm{~s}^{-1}\right)$ and the (b) ozone flux $\left(\mathrm{Tg} \mathrm{yr}^{-1}\right)$ averaged on the $100 \mathrm{hPa}$ surface between 30 and $90^{\circ} \mathrm{N}$ for each ensemble simulation (colored). The ensemble average fields are fit cubically and are shown in black. A 12-month smoothing is used for all fields.
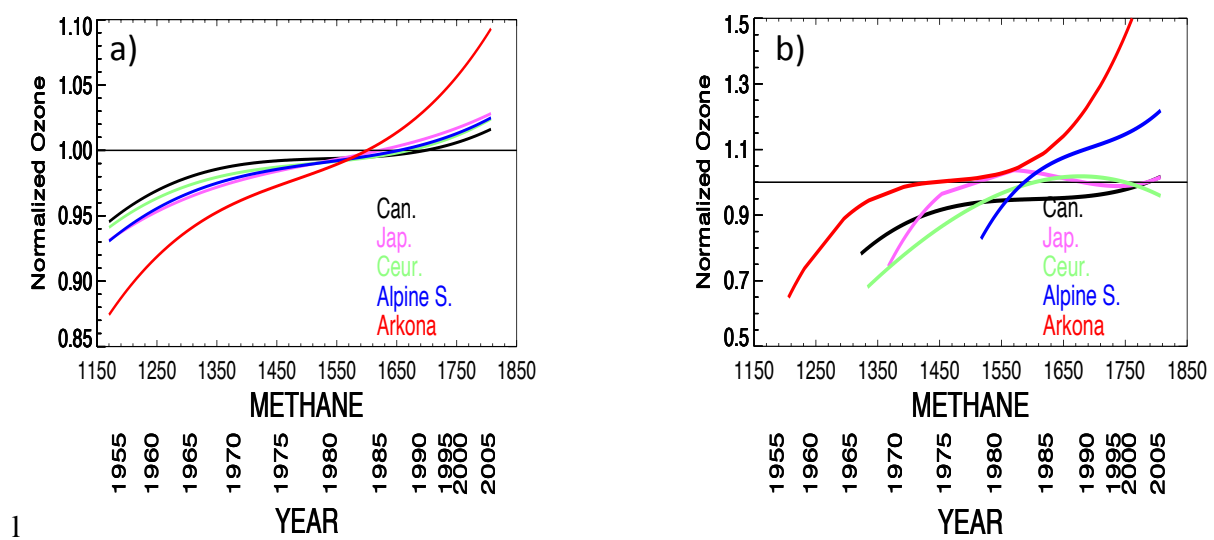

Figure 8. (a) Simulated and (b) measured cubic fits of normalized ozone vs. global surface methane concentration for various long-term tropospheric measurement sites: the regional average of the Canadian (Can.), central European (Ceur.) and Japanese (Jap.) ozonesonde sites at $500 \mathrm{hPa}$, the average of the Jungfraujoch and Zugspitze sites (Alpine S.) and the Arkona surface site. Ozone is normalized by its 1980-1985 concentration at each site. Globally averaged methane is from the WACCM simulation. The year corresponding to the methane concentration is given. Simulated ozone is the ensemble mean.

At all sites, the simulated ozone increase with respect to methane is relatively fast between approximately 1953-1970 and 1990-2005, but is noticeably slower from 1970 to 1990. As the simulated surface $\mathrm{NO}_{\mathrm{x}}$ emissions are not increasing over the course of the simulation, we would expect the ozone production from the simulated methane $\mathrm{NO}_{\mathrm{x}}$ tropospheric chemistry to be approximately linear in methane. The simulated long-term non-linearity in ozone with respect to methane is consistent with the long-term modulations in the flux of ozone from the stratosphere: the period of slow tropospheric ozone growth (from approximately 1970 to 1990) is coincident with the decrease in the flux of ozone from the stratosphere.

It is difficult to draw any strong conclusions through a comparison of the simulated and measured ozone-methane curves (Fig. 8). The measured curves show a variety of different shapes. The measured curve over central Europe at $500 \mathrm{hPa}$ reaches a maximum near 1990 and then decreases. This curve is undoubtedly impacted by the high measured ozone concentrations over central Europe in the 1980s (Fig. 4). These early measurements should be treated with caution. The Japanese $500 \mathrm{hPa}$ measurements also suggest an early ozone maximum (in the 1980s), but show an ozone increase in the latest period. Other measured curves show an ozone increase near the end of the period. The cubic fit to the data is likely sensitive to the length of the data record as well as to the beginning and end points of the measured time series.

In the measured curves it is difficult, if not impossible, to separate out the impact of changes in the emissions of ozone precursors from that due to changes in the influx of ozone from the stratosphere. If, for example, we concen- 
Table 3. Sensitivity coefficients (percent change in ozone to percent change in $\mathrm{CH}_{4}$ or the $100 \mathrm{hPa}$ ozone flux) between 12-month smoothed normalized simulated ozone with normalized globally averaged methane and the normalized lagged $30-90^{\circ} \mathrm{N}$ ozone flux at $100 \mathrm{hPa}$. Coefficients are given for the lag with the smallest chi squared. Variables are normalized by their average value from 1980 to 1985 .

\begin{tabular}{|c|c|c|c|c|c|}
\hline \multirow[t]{2}{*}{ Stations } & \multicolumn{2}{|c|}{ Sensitivity } & \multirow{2}{*}{$\begin{array}{l}\mathrm{Lag}^{1} \\
\text { (months) }\end{array}$} & \multirow[t]{2}{*}{ Corr $^{2}$} & \multirow[t]{2}{*}{ CHISQ } \\
\hline & $\mathrm{CH}_{4}$ & Flux & & & \\
\hline \multicolumn{6}{|l|}{$500 \mathrm{hPa}$} \\
\hline Canada & 0.15 & 0.25 & 5 & 0.86 & 0.071 \\
\hline N. Europe & 0.16 & 0.24 & 6 & 0.83 & 0.088 \\
\hline C. Europe & 0.18 & 0.17 & 5 & 0.77 & 0.072 \\
\hline Japan & 0.22 & 0.08 & 5 & 0.47 & 0.084 \\
\hline $30-90^{\circ} \mathrm{N}$ average $^{3}$ & 0.17 & 0.19 & 4 & 0.84 & 0.053 \\
\hline \multicolumn{6}{|l|}{ Surface } \\
\hline $\mathrm{JFJ} / \mathrm{ZUG}$ & 0.20 & 0.13 & 6 & 0.67 & 0.068 \\
\hline Lassen & 0.15 & 0.14 & 5 & 0.67 & 0.082 \\
\hline Arkona & 0.45 & 0.04 & $5^{4}$ & 0.11 & 0.581 \\
\hline Mace Head & 0.20 & 0.09 & 5 & $0.28^{5}$ & 0.307 \\
\hline $30-90^{\circ} \mathrm{N}$ average ${ }^{3}$ & 0.21 & 0.11 & 6 & 0.73 & 0.035 \\
\hline
\end{tabular}

${ }^{1}$ Lag in months between the ozone record and the $30-90^{\circ} \mathrm{N}$ averaged ozone flux resulting in the smallest regressed chi-squared. The lag is measured as the number of months by which the ozone flux lags the ozone concentration.

2 Correlation is between the regressed ozone record and the simulated ozone record after removing the regressed dependence on methane from each (see text). Values significant at the $99 \%$ level are shown in bold.

3 Average from 30 to $90^{\circ} \mathrm{N}$.

${ }^{4}$ There is no well defined minimum chi-squared at Arkona. We give coefficients at 5 months.

${ }^{5}$ Correlation is 0.49 for the point $10^{\circ} \mathrm{W}$ and $5^{\circ} \mathrm{N}$ of Mace Head.

trate on changes in the emissions of $\mathrm{NO}_{\mathrm{x}}$, the emissions increased rapidly in Europe from 1950 to 1980 by approximately $500 \%$ (Vestreng et al., 2009), flattened out between 1980 and 1990, and decreased thereafter. The US emissions stabilized following the clean air act of 1970 (EPA, 2000) after increasing by approximately $250 \%$ from 1950 to 1970 . Emissions over eastern Asia increased by approximately $250 \%$ between 1980 and 2000, but were not commensurate with either US or European emissions until approximately 1995 (Ohara et al., 2007). Since the simulation does not include these changes in ozone precursor emissions it is not surprising that measured ozone changes (Fig. 8) are about a factor of three to four larger than those simulated. The measured sharp increase in ozone prior to 1970-1980 and then the transition to a flatter trend is consistent with the emission changes. After 1985, the shape of the various measured curves is not consistent with the emission trends.

The coefficients for the multiple regression of simulated normalized ozone against normalized methane and the normalized stratospheric $100 \mathrm{hPa}$ ozone flux (averaged from 30 to $90^{\circ} \mathrm{N}$ ) are given in Table 3 at various measurement sites and for the $30-90^{\circ} \mathrm{N}$ area-averaged ozone. The normalized fields are obtained by dividing the respective fields by their
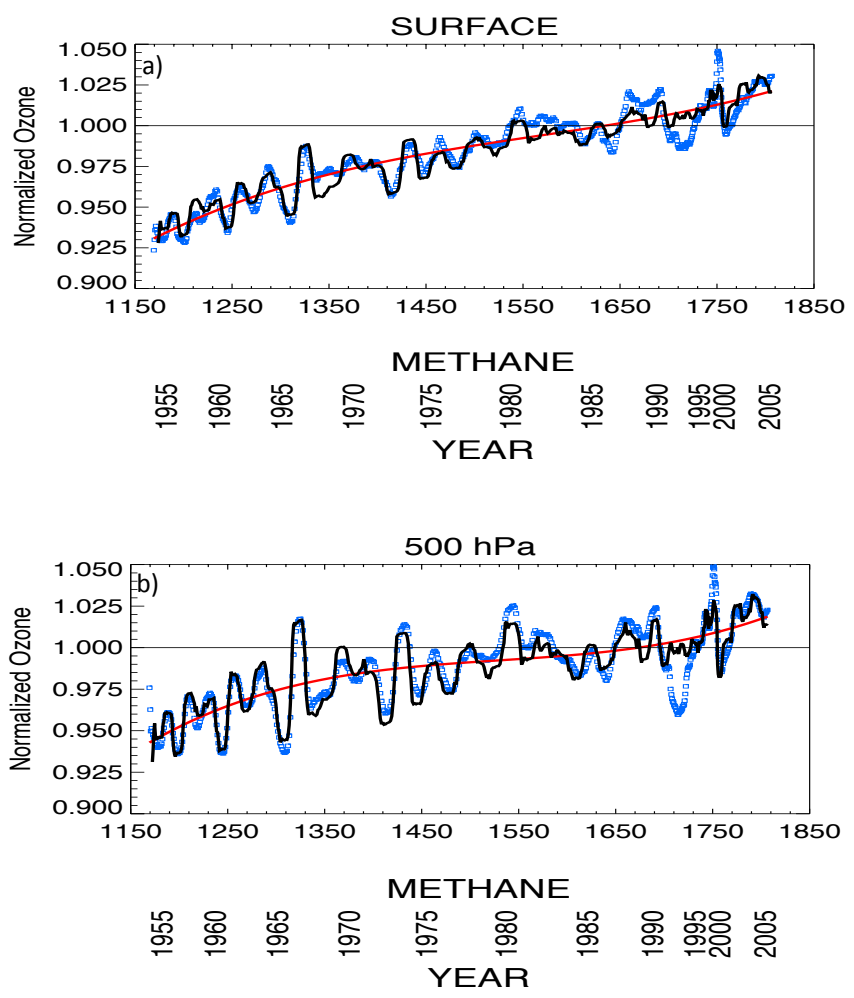

Figure 9. Simulated normalized ensemble mean ozone against global methane concentrations (blue squares), the cubic fit of normalized ozone against methane (red line) and the regressed fit (black line). Ozone is averaged from 30 to $90^{\circ} \mathrm{N}$ at (a) the surface and (b) $500 \mathrm{hPa}$. The year corresponding to the methane concentrations is also shown.

average value from 1980 to 1985 . In this regression we average across the four ensemble members. The best fit is obtained when the tropospheric response lags the ozone flux by approximately 5-6 months. This time lag is consistent with the relatively small lower stratospheric residual velocities (Fig. 7a). It is also roughly consistent with Liang et al. (2009) and the discussion therein that it takes 1 month for a tracer to cross the tropopause from the lower stratosphere, another month to descend to the mid-troposphere, and an additional month to reach the lower troposphere. In our study, we are including the lag from $100 \mathrm{hPa}$ to the tropopause. At all sites, correlations between the regressed fit and the simulated ozone are highly significant and greater than 0.9 (see Fig. 9). The sensitivity of normalized tropospheric ozone (i.e., the fractional change in tropospheric ozone) to fractional changes in methane and to fractional changes in the $100 \mathrm{hPa}$ ozone flux is roughly similar, about 10-20\% (Table 3 ). The sensitivity to the ozone flux is generally higher at $500 \mathrm{hPa}$ than at the surface, with the largest sensitivity at the northernmost $500 \mathrm{hPa}$ ozonesonde sites $(0.24-0.25)$. The sensitivity to methane is higher at the surface than at $500 \mathrm{hPa}$ 
with the highest sensitivity at Arkona (0.45). The high sensitivity to methane at Arkona is likely due to the locally high $\mathrm{NO}_{\mathrm{x}}$ emissions at the site. We also note that the regressed fit is poorest at Arkona. The sensitivity of the overall $30-90^{\circ} \mathrm{N}$ averaged ozone concentration is similar to the sensitivity at the various sites. The sensitivity coefficients will likely be impacted by the tropospheric chemical mechanism, although the impact may not be large under background chemical conditions.

As discussed above the non-linearity in the simulated long-term tropospheric ozone trend with respect to methane can be largely ascribed to the long-term modulation of the ozone flux at $100 \mathrm{hPa}$. However, the regression also captures many of the short-term changes in the simulated ozone (Fig. 9). Since methane is only slowly changing, the shortterm ozone variability is due to variations in the flux of ozone across $100 \mathrm{hPa}$. Interestingly, the regressed fit does not capture the ensemble average ozone change during the Mt. Pinatubo period. The portion of the simulated ozone record not explained by methane changes is obtained by subtracting the dependence of ozone on methane (determined from the regressed fit) from the simulated ozone record. In Table 3, we give the correlation between this quantity and the vertical flux of ozone across $100 \mathrm{hPa}$ averaged from 30 to $90^{\circ} \mathrm{N}$. The area-averaged correlations are large, ranging from 0.84 at $500 \mathrm{hPa}$ to 0.73 at the surface. At $500 \mathrm{hPa}$, the correlation at individual sites is similar to the area-wide correlation, except over Japan, although even over Japan, the correlation is significant. At the surface, the correlations at elevated sites are similar to the area-wide correlation. The variability explained by the stratospheric flux is low and not significant at Arkona, situated in a region of relatively large local emissions. At Mace Head, the stratospheric flux is only marginally correlated with the simulated record (Table 3). The Mace Head site is significantly impacted by European emissions. Sampling the simulations northwest of Mace Head (by $10^{\circ}$ longitude west and by $5^{\circ}$ latitude north) significantly improves the correlation with the stratospheric ozone flux (Table 3). In the absence of daily output data from these simulations, it is likely that this displaced location will be more representative of the filtered baseline ozone measurements at Mace Head (Derwent et al., 2007; Simmonds et al., 2004) than sampling the model at the actual location of Mace Head. Hess and Zbinden (2013) found that stratospherically tagged ozone has a large influence on the variability at the Mace Head site.

\subsection{Response of tropospheric ozone to stratospheric ozone perturbations}

The large-scale area-averaged simulated ozone variability is highly correlated across vertical levels (Fig. 10) in all simulations. Neu et al. (2014) show that the correlation between stratospheric and tropospheric ozone is a good proxy for the relationship between tropospheric ozone and changes in STE. In this figure, we subtract out the linear growth of tropo- spheric ozone due to methane changes. Stratospheric ozone is not detrended in this analysis so the impact of stratospheric ozone depletion and recovery on long timescales is retained. Detrended tropospheric ozone at the 500 and $1000 \mathrm{hPa}$ levels is consistent with the long-term trends in stratospheric ozone: at both levels, detrended tropospheric ozone is a maximum near 1970 and a minimum during the period influenced by the Mt. Pinatubo eruption in the early 1990s. The shorter-term year-to-year fluctuations in ozone are highly correlated vertically in all simulations for each ensemble member. The correlation between the $150 \mathrm{hPa}$ area averaged ozone and the detrended tropospheric area averaged ozone at $500 \mathrm{hPa}$ reaches 0.80 with a lag of 3 months; the correlation between $150 \mathrm{hPa}$ ozone and surface ozone reaches 0.75 with a lag of 4 months; the correlation between area-averaged $500 \mathrm{hPa}$ ozone and the surface reaches 0.90 with a lag of 1 month. All these correlations are highly significant. Stratospheric-tropospheric correlations based on satellite data are smaller: Neu et al. (2014) find the correlation between the $40-50^{\circ} \mathrm{N} 150 \mathrm{hPa}$ ozone anomaly and that at $510 \mathrm{hPa}$ between $30-50^{\circ} \mathrm{N}$ is 0.40 . Hess and Zbinden (2013) also discussed large-scale simulated and measured ozone correlations between the lower stratosphere and the surface, and found the correlations to be significant. On a more regional or local scale, Tarasick (2005), Ordóñez et al. (2007), Thouret et al. (2006) and Terao et al. (2008) report significant measured correlations between stratospheric and tropospheric ozone. Tang et al. (2013) simulate the impact on tropospheric ozone of the large-scale stratospheric ozone reductions during the Mt. Pinatubo period.

The overall response of $500 \mathrm{hPa}$ ozone (averaged from 30 to $90^{\circ} \mathrm{N}$ ) to changes in $150 \mathrm{hPa}$ ozone (averaged from 30 to $90^{\circ} \mathrm{N}$ ) is $0.018 \mathrm{ppb} \mathrm{ppb}^{-1}$ (not shown). Given a $150 \mathrm{ppb}$ decrease in stratospheric ozone between approximately 1970 and the Mt. Pinatubo period, the resulting ozone at 500 $\mathrm{hPa}$ would have decreased by $2.7 \mathrm{ppb}$ as a result. At individual stations, the tropospheric response is stronger. The slope of surface ozone to stratospheric perturbations is $0.007 \mathrm{ppb} \mathrm{ppb}^{-1}$. This implies an area-wide surface ozone decrease of approximately $1 \mathrm{ppb}$ due to stratospheric ozone depletion. The overall response at the surface to ozone perturbations at $500 \mathrm{hPa}$ is $0.38 \mathrm{ppb} \mathrm{ppb}^{-1}$. As shown by Hess and Zbinden (2013), Tang et al. (2013) and Zeng and Pyle (2005) the tropospheric ozone response to increased STE is buffered by decreases in tropospheric chemical ozone loss and deposition.

\subsection{Coupled modes of variability}

The spatial pattern of ozone variability at $150,500 \mathrm{hPa}$ and the surface is analyzed using empirical orthogonal function (EOF) analysis. This analysis separates ozone variability into orthogonal basis functions. Each function is specified by a spatial pattern (with a dependence on location only) and a time series for the temporal variations of this pattern with a dependence only on time (the principal component time 

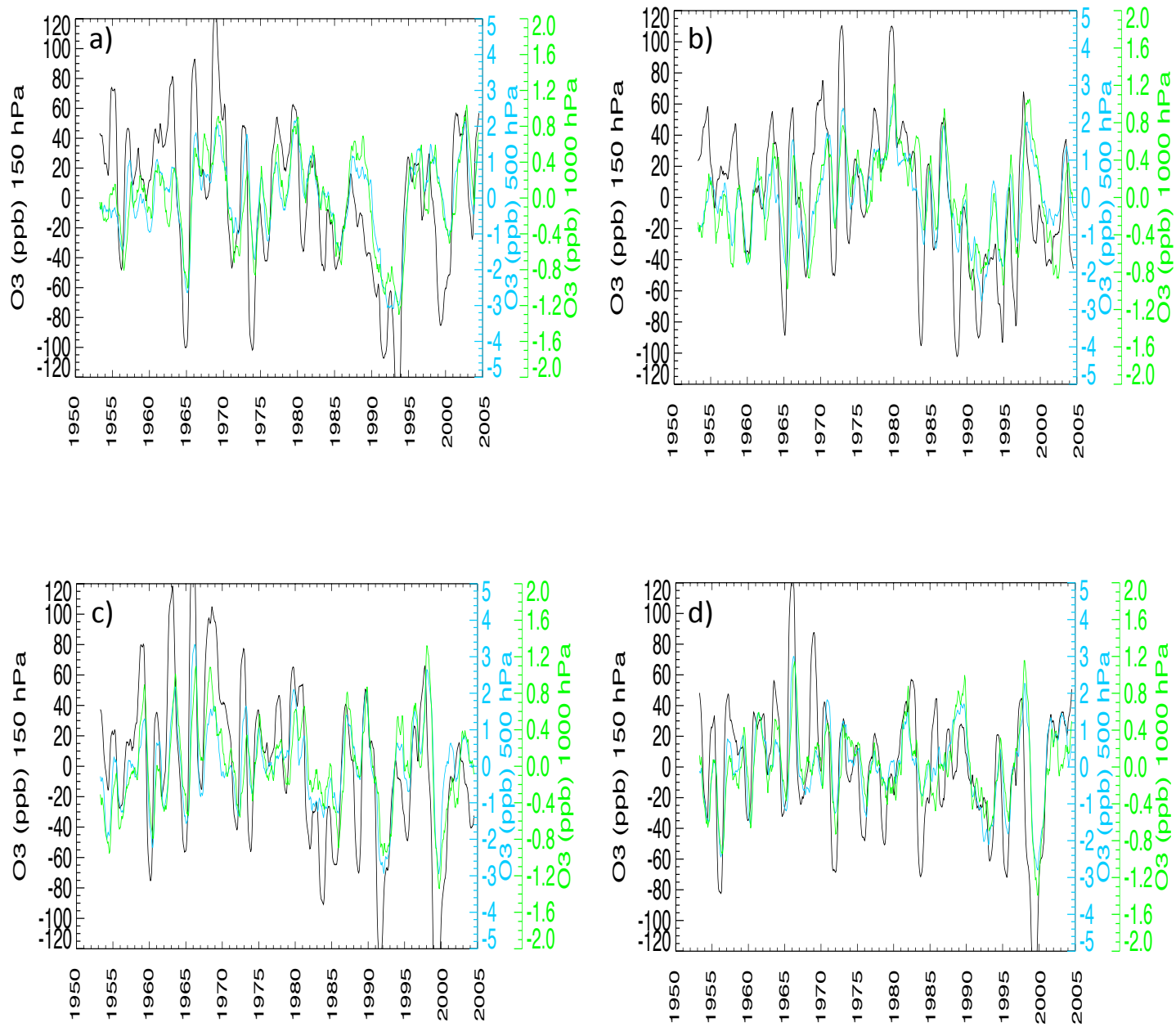

Figure 10. Ozone deviations (ppb) averaged from 30 to $90^{\circ} \mathrm{N}$ for each of the four WACCM ensemble members at $150 \mathrm{hPa}$ (black), $500 \mathrm{hPa}$ (blue) and the surface (green). The linear dependence on global methane has been removed from the ozone records at 500 and $1000 \mathrm{hPa}$. Monthly ozone deviations are smoothed over 12 months. Deviations are from ozone averaged over the entire simulation. Note the different scales for each level.

series). EOF analysis allows an understanding of the geographic variability of the ozone record and relates the variability at different locations.

The EOF analysis is conducted on the detrended ozone record at all locations from 30 to $90^{\circ} \mathrm{N}$. The ozone record at the surface and $500 \mathrm{hPa}$ are detrended by regressing ozone against global methane concentrations; the ozone record at $150 \mathrm{hPa}$ is detrended with respect to time. The first EOF component at all three levels is given in Fig. 11. The EOF is normalized so that its value gives the standard deviation of the ozone variations due to this EOF; the sign specifies the phase difference between the ozone variations explained by the EOF. Points with different signs have opposite temporal phases. The first EOF captures from 40 to $48 \%$ of the ozone variability at the surface, 71 to $77 \%$ of the variability at $500 \mathrm{hPa}$, and 79 to $85 \%$ of the variability at $150 \mathrm{hPa}$ (Table 4). For each ensemble member, the correlation between the temporal variability of the principal component and the detrended area average ozone is very high (greater than 0.95 on all three levels, not shown). Thus, the temporal variation in EOFs is closely related to the area averaged ozone variations. However, the use of EOFs refines the simple use of area averages by showing geographical differences in the pattern of variability with a better statistical characterization of the variability.

For each ensemble member, the principal component time series are highly correlated across vertical levels (Fig. 13 and Table 4), suggesting that the modes of variability isolated by the EOF analysis are physically deep (i.e., they span from at least the surface to $150 \mathrm{hPa}$ ). Due to the large ozone gradients between the stratosphere and troposphere, it is difficult to escape the conclusion that the coupled variability between the stratospheric and tropospheric levels is linked through the transport of high stratospheric ozone concentrations to the troposphere (see Neu et al., 2014). This is consistent with the analysis of Hess and Zbinden (2013). As discussed be- 
Table 4. Explained variances of the first EOF and the correlations between their principal components on various model levels.

\begin{tabular}{lllll}
\hline Level & $\begin{array}{l}\text { Explained } \\
\text { variance }\end{array}$ & $\begin{array}{l}\text { Correlation } \\
150 \mathrm{hPa}\end{array}$ & $\begin{array}{l}\text { Correlation } \\
\mathrm{O}_{3} \text { flux }\end{array}$ & \\
& & $\mathrm{PC}^{2}$ & $100 \mathrm{hPa}^{3}$ & \\
\hline $150 \mathrm{hPa}$ & $79-85 \%$ & $\mathrm{NA}$ & $0.85(0.43)$ & $2(2)$ \\
$500 \mathrm{hPa}$ & $71-77 \%$ & 0.78 & $0.85(0.50)$ & $5(5)$ \\
surface & $40-48 \%$ & 0.66 & $0.73(0.34)$ & $6(6)$ \\
\hline
\end{tabular}

${ }^{1}$ Range of variances explained by the 1 st EOF over the model ensembles.

2 Temporal correlation between principal components at the surface and $500 \mathrm{hPa}$ and the principal component at $150 \mathrm{hPa}$. The correlation is computed between levels of the same ensemble simulation; however, the overall correlation coefficient comprises the relationship for all ensembles. All correlations are significant at the $99 \%$ level.

${ }^{3}$ Temporal lagged correlation between principal components on various pressure levels and the $30-90^{\circ} \mathrm{N}$ averaged ozone flux at $100 \mathrm{hPa}$. The correlation without parentheses is between the ensemble averaged principal component and the ensemble averaged $30-90^{\circ} \mathrm{N}$ averaged ozone flux at $100 \mathrm{hPa}$. The correlation in parentheses is between the principal component and the $30-90^{\circ} \mathrm{N} 100 \mathrm{hPa}$ ozone flux for each individual ensemble member. All correlations are significant at the $99 \%$ level.

${ }^{4} \mathrm{Lag}$ (months) of the maximum correlation between the ozone flux and the principal component: without parentheses for the ensemble average; and with parentheses for individual ensemble members. The lag is measured as the number of months by which the ozone flux lags the principal component.
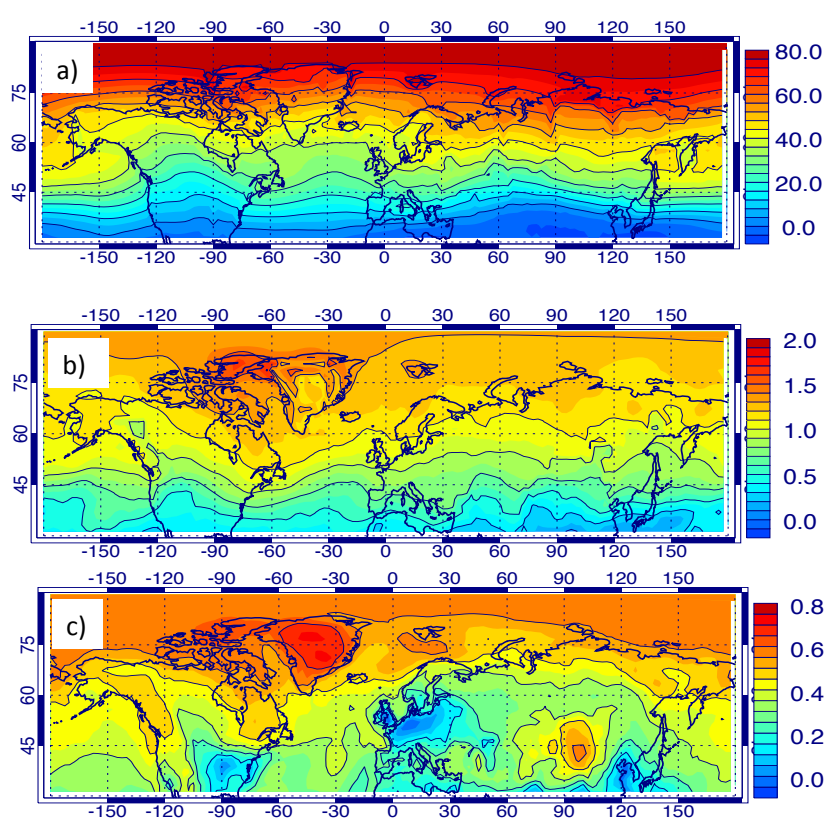

Figure 11. Normalized first EOF component of detrended ozone at (a) $150 \mathrm{hPa}$, (b) $500 \mathrm{hPa}$ and (c) the surface. Shown is the average for all four ensembles of the EOF multiplied by the standard deviation of the principal component. The absolute value of the result shows the variability of ozone (ppb) expected due to variations in the first EOF component; the sign of the result shows the relation between variability at different locations.

low, the geographical pattern of the variability supports this conclusion.

The ensemble average of the area-averaged $30-90^{\circ} \mathrm{N}$ ozone flux at $100 \mathrm{hPa}$ explains $40 \%$ of the variability of the ensemble average principal component time series at the surface, $58 \%$ at $500 \mathrm{hPa}$ and $69 \%$ at $150 \mathrm{hPa}$ (with a lag of 2 to 6 months) (Table 4). The lag increases as one descends in the atmosphere consistent with timescales for the transport of ozone from the lowermost stratosphere to the surface. The correlation between the ozone flux for each ensemble member and the principal component time series for that ensemble member (instead of the correlation between the ensemble averages) reduces the variability explained by the ozone flux to between approximately 12 and $25 \%$ (Table 4). Evidently the ensemble average of the respective time series removes uncorrelated "noise" from each record. Analogous results also occur in an analysis of the area-averaged ozone at each level (not shown).

The geographical pattern of the EOFs relates variability between different regions. On each level the variability explained by each EOF is mostly the same sign (Fig. 11) consistent with the relationship between the principal component time series and that of area averaged $30-90^{\circ} \mathrm{N}$ ozone. At all levels, the ozone variability attributed to the first principal component is largest to the north and decreases to the south. The equatorward decrease in the amplitude of the EOF is less at the surface, consistent with the transport of stratospherically derived ozone downwards and southwards along isentropic surfaces. The standard deviation of the ozone variation due to the first EOF reaches $0.6-0.8 \mathrm{ppb}$ at the surface, $1.5-2.0 \mathrm{ppb}$ at $500 \mathrm{hPa}$ and almost $80 \mathrm{ppb}$ at $150 \mathrm{hPa}$. Obviously, at times the amplitude of the first principal component can well exceed these values. At the end of this section, we examine the variation of the principal component at selected measurement locations.

Hess and Zbinden (2013) and Zbinden et al. (2006) noted that the temporal variability of the ozone record is often similar over widespread geographical regions. The large percent of variability explained by the first EOF, the global nature of this mode, and the fact that it is of the same sign over large regions of the $\mathrm{NH}$ extratropics, demonstrate the connection of the temporal ozone record between geographically distant regions. The vertical coupling between the principal component time series of the first EOF and its relation to the $100 \mathrm{hPa}$ ozone flux suggests that the root cause of this widespread variability is due to coupled modes of stratosphere-troposphere variability related to STE. It seems likely that the region west of Ireland where the surface amplitude of the first EOF is comparatively large (Fig. 11) is captured by the measurements at the Mace Head observatory, particularly when the measurements are sampled for "baseline" tropospheric air. This region of large amplitude in the surface EOF pattern (Fig. 11c) helps to explain the relation between the ozone variability sampled at Mace Head and the variability sampled at the high alpine sites over Europe (e.g., Hess and Zbinden, 2013), where the amplitude of the first EOF is also comparatively large (not shown). At the European Alpine sites, it is appropriate to analyze the simulations at the site elevation and not at the model surface: 
the site elevation is not resolved in the simulations, and they predominantly sample free tropospheric air. The EOF representative of the elevation of these sites does not resemble the surface EOF (Fig. 11c), but more closely resembles the EOF at $500 \mathrm{hPa}$ (Fig. 11b). The $150 \mathrm{hPa}$ and $500 \mathrm{hPa}$ ozonesondes over Canada, northern Europe and central Europe also have similar amplitudes of the primary EOF. This suggests that the variability between these regions should be highly related, as shown in Hess and Zbinden (2013). The amplitude of this mode of variability is less over Japan at both 150 and $500 \mathrm{hPa}$ : the ozone variability over Japan is more likely to be swamped by other modes of variability. Hess and Zbinden (2013) show the variability over Japan is not well correlated with the variability in other regions.

At the surface (Fig. 11c), the first EOF is small to occasionally negative over the regions with high emissions: over the eastern US, Europe and eastern Asia. In these regions, variability is likely governed by local photochemistry and is less influenced by the large-scale processes examined here. In addition, since ozone has a different seasonality between these locations and the more remote regions, annually averaged ozone is likely to reflect different processes. Over the US and Europe, surface ozone tends to maximize in summer; at other more remote locations, ozone is minimum during the summer months. Over Asia, the seasonal variability is likely complicated by the summer monsoon. The EOF pattern as a whole is dominated by variability over remote regions.

The geographic pattern of ozone variability associated with the first EOF reflects known patterns of stratospheretroposphere exchange (Fig. 11), particularly at the surface. At the surface, high regions of variability extend southward over the eastern Atlantic Ocean, the eastern Pacific Ocean and the western US. Lin et al. (2012), James (2003) and Sprenger (2003) emphasize the importance of deep stratospheric ozone intrusions over the western US coast and eastern Pacific. Here, downward ozone transport from stratospheric sources of ozone can descend along the eastern flank of the Pacific anticyclone. The outlines of this anti-cyclonic transport of ozone are particularly evident at the surface and $500 \mathrm{hPa}$ in the first EOF (Fig. 11). Sprenger (2003) also shows that the Atlantic basin is a region of significant stratosphere to troposphere transport of air with a climatological region of deep stratosphere to troposphere exchange extending from southern Greenland to Ireland.

While the surface EOFs calculated for ensemble members are overall qualitatively similar, rather large differences are notable at some locations between the different ensemble members (Fig. 12). In particular, the western US and Ireland show large differences between different simulations, suggesting the importance of unforced model variability in these regions. For example, in one ensemble member, ozone variability off the southwestern coast of the US attributed to the first EOF exceeds $0.6 \mathrm{ppb}$, while in another member, it is less than approximately $0.2 \mathrm{ppb}$ (Fig. 12). The average variability for all the ensembles off the southwestern coast
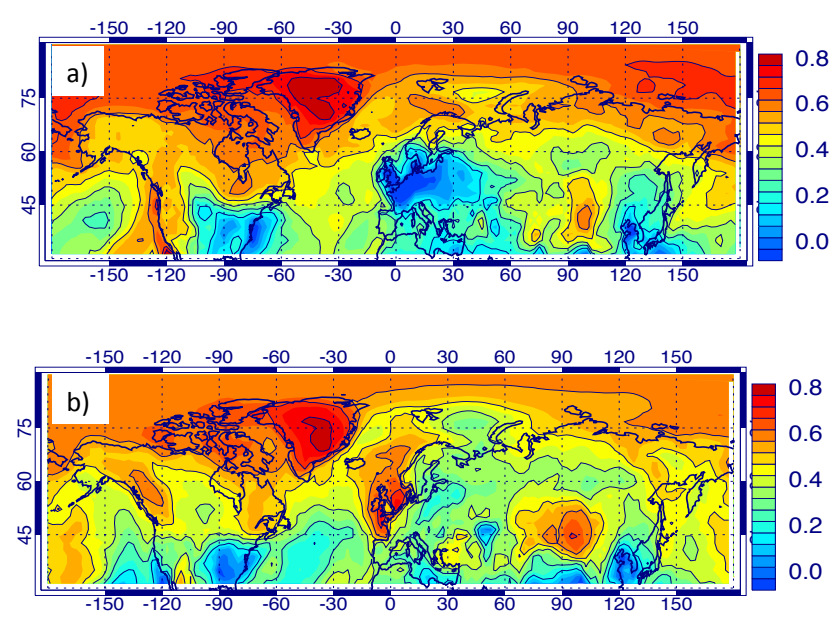

Figure 12. As in Fig. 11 but for the normalized first EOF component of detrended ozone at the surface for two different ensemble members.

of the US at the surface is approximately $0.4 \mathrm{ppb}$ (Fig. 11). The magnitude of the first EOF off Ireland at the surface also varies greatly between ensemble members: in one ensemble member, the variability attributed to the first EOF is approximately $0.7 \mathrm{ppb}$ near Ireland; in another ensemble member, it is close to zero. The ensemble mean is close to $0.2 \mathrm{ppb}$ (Fig. 11).

The time series of the first principal component from each ensemble simulation show little relation during some periods, but during others the ensembles show strong similarities at all levels (Fig. 13). Many of the events where the ensembles show similar behavior appear to be associated with ENSO (Fig. 13): the pronounced negative and positive ozone anomalies during all simulations and all levels during 1966 and 1967 appear to be associated with the negative and positive ENSO indexes that occur 6-12 months earlier; an ozone peak is also common to all levels and all ensembles in 1998-1999 following the El Niño of 1998. The $1998 \mathrm{El}$ Niño event has been linked in the literature to a tropospheric ozone anomaly (Koumoutsaris et al., 2008; Voulgarakis et al., 2011). However, we find the correlation between ENSO and the principal component time series is small at all levels (less than 0.23) (not shown). (The correlation is also small on all levels between the ENSO signal and the area averaged 30$90^{\circ} \mathrm{N}$ ozone.) We note that Hsu and Prather (2009) also did not find a relation between ENSO and STE, although Zeng and Pyle (2005) show a strong correlation. Indeed the impact of ENSO on stratospheric circulation statistics via associated changes in stratospheric wave driving, and in particular an increase in the downwards residual velocity at extratropical latitudes during warm ENSO events, provides a mechanism whereby ENSO impacts the stratospheric-tropospheric exchange of ozone (Calvo et al., 2010). However, a careful examination of the ozone perturbations based on a compilation of high-index El Niño events in Calvo et al. (2010) indicates 

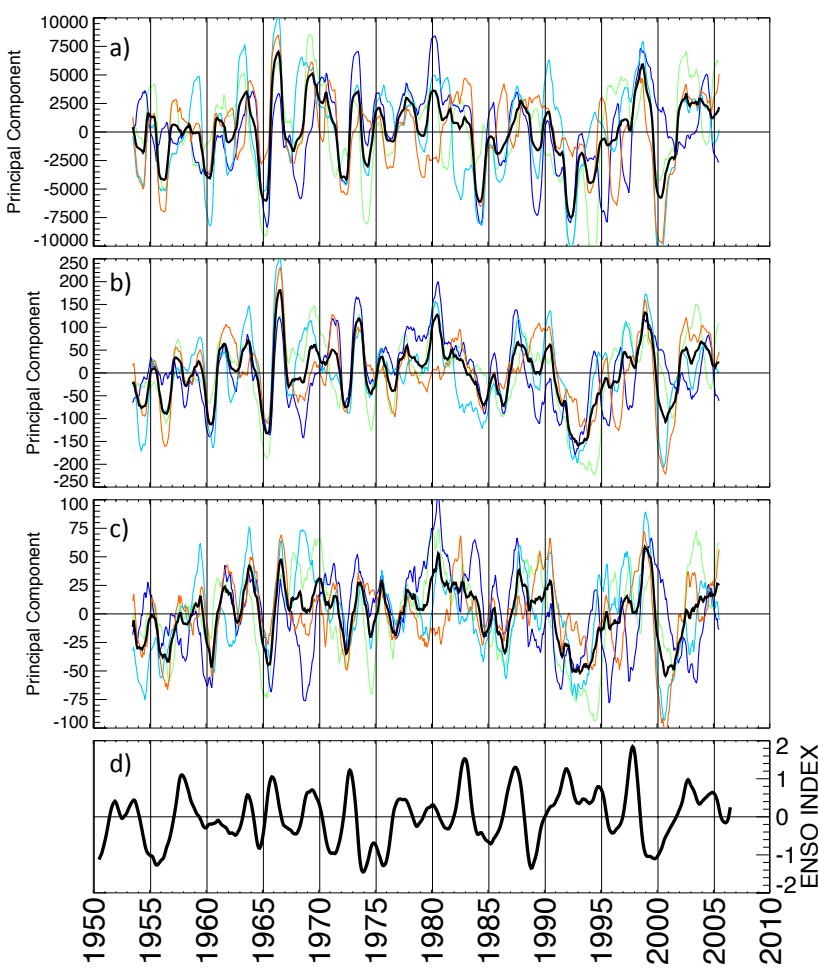

YEAR

Figure 13. Timeseries of the principal component for the first EOF of ozone from $30-90^{\circ} \mathrm{N}$ for each ensemble simulation (color) and for the ensemble mean (black) at (a) $150 \mathrm{hPa}$, (b) $500 \mathrm{hPa}$ and (c) the surface. The Ocean Nino Index (ONI) based on sea surface temperature anomalies in the Niño 3.4 region is given in the lower panel.

that significant extratropical ozone perturbations do not persist below about $10 \mathrm{~km}$. In Zeng and Pyle (2005), the ENSO index and STE were only correlated between 1990 and 2002, a relatively short period compared to the present study. The simulations described in Zeng and Pyle (2005) did not include the forcing due to the QBO or volcanoes included in the present study, forcings that may mask an underlying ENSO signal. Neu et al. (2014) were not able to isolate the impact of ENSO from that of the QBO on extratropical tropospheric ozone for the period from 2005 to 2011. The particular period examined in Zeng and Pyle (2005) (1990-2002) was dominated by large events: the 1998-1999 positive ozone anomaly associated with El Niño (Koumoutsaris et al., 2008; Voulgarakis et al., 2011) and the negative anomaly in 2000-2001 that can be associated with La Niña. Figure 12 suggests that only upon occasion is ENSO associated with the strong forcing of ozone anomalies, although, over the long run, the correlation between the two is small.

Sampled at characteristic locations $(500 \mathrm{hPa}$ Canadian sites, Mace Head, Lassen and the European Alpine sites) (Fig. 14), it is apparent that the ozone variability due to the principal component time series explains a substantial fraction of the overall simulated variability. Over the course of the simulation, the correlation between ozone variability and the principal component time series is 0.97 for all ensemble simulations over the Canadian $500 \mathrm{hPa}$ ozonesonde sites, between 0.64 and 0.80 for the ensemble simulations over the European alpine sites, between 0.48 and 0.70 for the ensemble simulations at Mace Head, and between 0.09 and 0.74 for the ensemble simulations at Lassen. Note however that, at Lassen, three of the simulations have correlations above 0.60 . To better sample baseline ozone conditions at Mace Head we have sampled the model at the point $10^{\circ} \mathrm{W}$ and $5^{\circ} \mathrm{N}$ of the actual observatory location in Fig. 14. The correlation between the model and measurements has been described above (Sect. 3; also see Table 2).

Note in particular, the ozone increase between the measured ozone minimum in the early 1990s and the ozone maximum near 1998-1999 at the disparate locations shown in Fig. 14 is not only captured in the simulated ozone record but also in the principal component time series. At the four sites in Fig. 14, the measured ozone jump during the 1990s (defined here as the maximum minus minimum annually averaged ozone during the 1990s, where the ozone has not been detrended) is $6.6 \mathrm{ppb}$ at Mace Head, 7.4 ppb at the European Alpine sites, 9.1 ppb at Lassen and $12.6 \mathrm{ppb}$ at the Canadian ozonesonde stations. The simulations capture approximately $50 \%$ of the measured increase at all stations, ranging from $47 \%$ over the Canadian stations to $56 \%$ at Mace Head. A regression against methane over the entire model simulation shows that increases in methane explain a relatively small fraction of the ozone increase during the 1990s at these sites: $0.8 \mathrm{ppbdecade}^{-1}$ at the Lassen site, $0.27 \mathrm{ppb}$ decade $^{-1}$ over Canada, $0.39 \mathrm{ppb}$ decade $^{-1}$ at Mace Head and 0.27 ppb decade $^{-1}$ at the European Alpine sites. In fact, much of the simulated ozone increase at these sites can be traced to the principal component time series at these sites. Over Canada, the European Alpine sites, Lassen and Mace Head changes in the principal component account for 100 , 68,49 and $43 \%$ of the simulated ozone jump, showing that much of the jump during this period can be traced to changes in this global mode of variability. As argued above, the vertical correlation of the ozone principal component time series from the surface through the lower stratosphere, as well as their correlation with the $100 \mathrm{hPa}$ ozone flux, suggests that changes in the principal component are consistent with changes in the STE of ozone. Hess and Zbinden (2013) show that much of the measured ozone change during the 1990s at a variety of tropospheric sites could be traced to increases in the stratospheric portion of ozone.

Ozone increases measured on the western coast of the US at a variety of stations have been ascribed to increasing Asian emissions (e.g., Cooper et al., 2010; Parrish et al., 2012). However, the results here show substantial ozone increases have occurred during the 1990s over a wide variety of sites, many of them substantially removed from Asian emissions. 

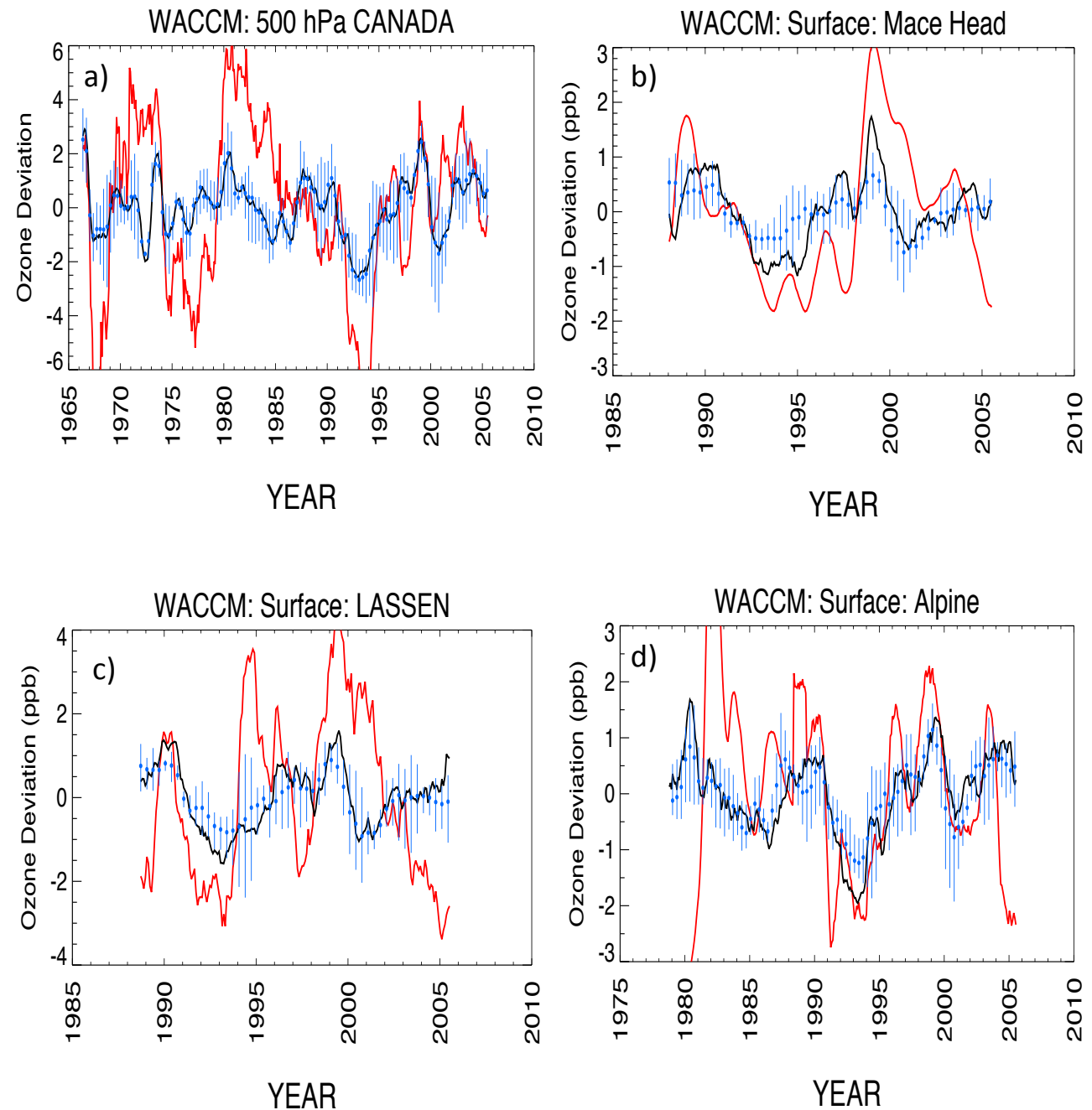

Figure 14. 12-month smoothed ozone deviations (ppb) for (a) the $500 \mathrm{hPa}$ Canadian ozonesondes and the surface sites at (b) Mace Head, (c) Lassen, and (d) the European Alps (note the different scales in each figure): detrended measurements (red), ensemble average detrended ozone (black), and the time variation of the first EOF (blue), where the vertical blue lines bracket the range of the EOF over the ensemble members and the blue dot gives the ensemble average EOF. In each case, ozone deviations are detrended against globally averaged methane over the common range of simulated and measured ozone.

In addition, the simulations, with no change in emissions, capture almost $50 \%$ of the observed ozone jump during the 1990s, including the changes at Lassen. This suggests that a large portion of the measured jump is not due to changes in emissions, but can be traced to changes in a global mode of ozone variability. This emphasizes the difficulty in the attribution of ozone changes, but also the importance of understanding the importance of natural variability in isolating the role of emissions in modifying ozone concentrations.

\section{Conclusions}

We have analyzed an ensemble of four free running simulations from 1953 to 2005 using the Whole Atmosphere Community Climate Model (WACCM). The simulations are forced by time changes in observed sea-surface tem- peratures, concentrations of greenhouse gases (including methane), stratospheric ozone depleting species, an externally forced quasi-biennial oscillation, solar variability and stratospheric sulfate surface area density (SAD). In the stratosphere, WACCM employs a sophisticated chemical mechanism. In the troposphere, only the basic tropospheric $\mathrm{NO}_{\mathrm{x}}-\mathrm{CH}_{4}$ chemistry is used, where the $\mathrm{NO}_{\mathrm{x}}$ surface emissions remain interannually constant. The relation between tropospheric interannual ozone variability and lower stratospheric interannual ozone variability is analyzed from 30 to $90^{\circ} \mathrm{N}$

Despite the simplicity of the tropospheric chemistry, the simulations capture the measured $\mathrm{NH}$ background ozone interannual variability to a surprising extent. Particularly for the period after 1990, the simulated detrended ozone is sig- 
nificantly correlated with the $500 \mathrm{hPa}$ ozonesonde measurements over northern Europe, central Europe and Canada (but not over Japan) and over surface measurement sites at Mace Head and the alpine sites over Europe (but not at Lassen or Arkona). We argue that the Arkona site (in Germany) is influenced by fresh anthropogenic emissions that may not be accurately captured with the simple tropospheric chemistry in these simulations. While the simulation appears to capture some aspects of the Lassen record, the large ozone trend in the measurements makes a simple comparison difficult. Prior to 1990 , there are fewer measurements, and the reliability of the measurements decreases. However, even during this period, the simulated ozone record is significantly correlated with the measured record at a number of locations.

It is not a foregone conclusion that the simulated detrended ozone should be correlated with the measurements in the first place, as the model dynamics are internally calculated. The fact that the model and observations are significantly correlated implies the importance of external forcing in determining the ozone variability. Indeed, the interannual simulated ozone record shows periods when the ozone variability appears to have little relation between the different model ensemble simulations. At these times, the applied external forcing does not exert a strong control on the ozone variability and the variability is likely dominated by internal model variability. However, the periods when the ensemble simulations show little similarity are punctuated by times when the variability between all the ensembles show strong agreement, suggesting the importance of a common forcing mechanism. At the sites examined, the correlation between the different detrended ensemble members ranges from approximately $0.24-0.44$ at the surface to $0.4-0.5$ at 500 and $150 \mathrm{hPa}$. The decade of the 1990s, in fact, may be particularly impacted by external forcing due to the influence of Mt. Pinatubo during the early part of the decade and the impact of the $1998 \mathrm{El}$ Niño toward the end of the decade.

There appears to be some association between the punctuated periods when all ensembles show strong agreement and ENSO. However, we do not find that these periods occur with all ENSOs, even if the ENSO is particularly strong. We find little relation between an index of ENSO and large-scale tropospheric ozone variability over the long-term record. We argue the length of the simulated record in the current study and the inclusion of volcanic and QBO forcing may explain the difference between this study and earlier work (e.g., Zeng and Pyle, 2005).

The simulated curves of tropospheric ozone vs. methane at a number of sites show a relatively rapid ozone increase prior to 1970 , a subsequent slow down in the rate of ozone increase from 1970 to 1985, but subsequent increased ozone growth after approximately 1990. The measured curves are strongly impacted by changes in ozone precursor emissions and thus despite some similarities with the simulations remain difficult to interpret with respect to STE. The ensemble average tropospheric ozone record can largely be explained as a linear combination of the $30-90^{\circ} \mathrm{N}$ area averaged $100 \mathrm{hPa}$ ozone flux and the global methane concentration. We use the former quantity as a proxy for STE. The long-term nonlinear rate of ozone increase with respect to methane can be explained by changes in the downward ozone flux across the $100 \mathrm{hPa}$ level. As expected from the imposed change in greenhouse gas forcing, the strength of the residual circulation increases throughout the simulations. This alone would act to increase the downward extratropical $\mathrm{NH}$ stratospheric ozone flux, with a resulting increase in tropospheric ozone; however, stratospheric ozone depletion counteracts this. As a consequence the $100 \mathrm{hPa}$ ozone flux decreases between approximately 1970 and 1990 and the rate of growth of tropospheric ozone with respect to methane slows. Subsequent to Mt. Pinatubo, ozone increases in the extratropical NH stratosphere. This acts to increase the $100 \mathrm{hPa}$ stratospheric ozone flux with resulting increases in tropospheric ozone. The multivariate linear regression of ozone against methane and the $100 \mathrm{hPa}$ ozone flux gives an approximate $20 \%$ sensitivity to changes in methane (percent change in ozone to percent change in methane); the average sensitivity to the ozone flux is $19 \%$ at $500 \mathrm{hPa}$ and $11 \%$ at the surface. Without ozone depletion, the approximate $15 \%$ increase in the simulated residual circulation from 1952 to 2005 would have resulted in a consequent $1.5 \%$ increase in surface ozone in the NH extratropics. Ozone depletion has reduced this increase by approximately half. Extrapolating these changes, a $30 \%$ increase in the ozone flux by 2100 (Hegglin and Shepherd, 2009) would result in $3 \%$ increase in surface ozone and a $6 \%$ increase in $500 \mathrm{hPa}$ ozone. In contrast, the satellite-based study of Neu et al. (2014) suggests that an increase in the stratospheric circulation by $40 \%$ would lead to a tropospheric ozone increase of $2 \%$.

On an interannual timescale, changes in the ensemble averaged $100 \mathrm{hPa}$ ozone flux (averaged from 30 to $90^{\circ} \mathrm{N}$ ) explain $70 \%$ of the ensemble averaged extratropical detrended ozone variability at $500 \mathrm{hPa}$ and $55 \%$ of the ensemble averaged detrended ozone variability at the surface. In regions of large emissions (e.g., Arkona), the variability explained is much less. Sampling "baseline" air just to the northwest of Mace Head suggests that variations in the ozone flux explain almost $25 \%$ of the variability of the "baseline" tropospheric ozone variability at Mace Head.

The first empirical orthogonal function (EOF) of $30-90^{\circ} \mathrm{N}$ ozone variability explains from $40 \%$ of the ozone variability at the surface to over $80 \%$ of the ozone variability at $150 \mathrm{hPa}$. The spatial pattern of this EOF at the surface is consistent with expected patterns of stratosphere-troposphere exchange, with a maximum off the western coast of the US. The EOF also shows relatively high amplitudes off the western coast of Ireland. The EOF has a small amplitude over regions with significant emissions of ozone precursors. The principal component time series associated with the first EOF are highly correlated in the vertical. The ensemble average principal component time series is also highly correlated with 
the ensemble average $100 \mathrm{hPa}$ ozone flux and is highly correlated with the ensemble averaged $30-90^{\circ} \mathrm{N}$ ozone average.

The interannual ozone variability at a number of individual sites over the course of the model simulation is largely explained by the variability in the principal component of the global EOF. At the stations examined in detail (the Canadian ozonesonde stations, the European Alpine sites, Lassen and Mace Head), the simulated ozone increase during the 1990s is about $50 \%$ of the measured increase. Over Canada, the European Alpine sites, Lassen and Mace Head changes in the principal component account for $100,68,49$ and $43 \%$ of the simulated ozone jump, showing that much of the jump during this period can be traced to changes in a global mode of ozone variability. This suggests that a large portion of the ozone increase in the 1990s as measured at a number of sites is not due to changes in emissions, but can be traced to changes in a global mode of ozone variability. This emphasizes the difficulty in the attribution of ozone changes, and the importance of natural variability in understanding the trends and variability of ozone (see Lin et al., 2014). The mode of variability analyzed here shows strong stratospheretroposphere coupling, demonstrating the importance of the stratosphere in the attribution of tropospheric ozone variability.

Despite the simplicity of the tropospheric chemistry used in these simulations, the simulations match the observed tropospheric variability to a large extent over locations sampling background tropospheric air. It is expected that the introduction of additional hydrocarbon chemistry as well as episodic emission variability (e.g., biomass burning) will introduce modes of variability not captured here as well as possibly dampen the basic modes of ozone variability analyzed above. Future simulations are necessary to fully explicate the importance of episodic emission variability and of the variability associated with hydrocarbon chemistry, including that of biogenic emissions. However, based on the agreement between these simulations and measurements, we hypothesize that the base-state modes of variability isolated here are fundamental to the coupled troposphere-stratosphere chemical system. The results obtained here are largely consistent with those in Hess and Zbinden (2013), where a sophisticated tropospheric chemical mechanism is employed along with a methodology for tagging stratospheric ozone. Hess and Zbinden (2013) also found that the exchange of ozone from the stratosphere to the troposphere explains a large fraction of extratropical tropospheric ozone variability, even at the surface, and that this variability operates on hemispheric spatial scales.

The high variability explained by this global mode and the fact that it is of the same sign over large regions of the NH extratropics demonstrates the relationship of the temporal ozone record between geographically distant tropospheric regions. Hess and Zbinden (2013) and Zbinden et al. (2006) noted that the temporal variability of the ozone record is often similar over widespread geographical regions. The vertical coupling between the principal component time series of the first EOF and its relation to the $100 \mathrm{hPa}$ ozone flux suggests that the root cause of this widespread variability is due to coupled modes of stratosphere-troposphere variability.

It is perhaps surprising that the stratosphere should be so important in explaining interannual tropospheric ozone variability. While early work suggested that much of the tropospheric ozone distribution can be explained with a stratospheric ozone source and a surface sink (Levy et al., 1985), for the past several decades, a newer paradigm emerged that de-emphasized the role of the stratosphere. It was recognized that tropospheric photochemical ozone production is almost 1 order of magnitude larger than the input from the stratosphere (e.g., Stevenson et al., 2006). However, the stratospheric source of ozone is widespread (Liang et al., 2009) and the lifetime of ozone is relatively large in the upper and middle stratosphere, allowing ozone from the stratosphere to be transported throughout the troposphere (Liang et al., 2009). By contrast, ozone production can be large near the surface, but on average this is compensated for by photochemical and surface ozone loss. The stratospheric source is particularly important in explaining the interannual variability of ozone away from regions of immediate photochemical production.

These results suggest the difficulty in the attribution of ozone changes without understanding the root causes of the natural variability of ozone. Simply examining changes in ozone precursor emissions, even on the decadal timescale, is insufficient to link changes in ozone to changes in emissions. A full attribution of ozone variability may require more sophisticated models with a good resolution of stratospheric processes.

Acknowledgements. The authors would like to thank the reviewers for their helpful comments. P. G. Hess would like to acknowledge NSF grant no. 1042787 for supporting this work. Work at LLNL was performed under the auspices of the US Department of Energy (DOE), Office of Science, Office of Biological and Environmental Research by Lawrence Livermore National Laboratory under contract DE-AC52-07NA27344 and supported by the Atmospheric Radiation Measurement Program of the Office of Science at the US Department of Energy. The CESM project is supported by the National Science Foundation and the US Department of Energy. The National Center for Atmospheric Research is operated by the University Corporation for Atmospheric Research under sponsorship of the National Science Foundation. We acknowledge the World Ozone and Ultraviolet Radiation Data Centre (WOUDC) for providing the ozonesonde data, the US National Park Service for providing Lassen NP ozone data, A. Volz-Thomas for the Arkona data, and D. Parrish for providing access to his surface composited ozone data sets.

Edited by: B. N. Duncan 


\section{References}

Andrews, D. G., Holton, J. R., and Leovy, C. B.: Middle Atmosphere Dynamics, Academic Press, New York, NY, USA, 489 pp., 1987.

Butchart, N., Scaife, A. A., Bourqui, M., de Grandpre, J., Hare, S. H. E., Kettleborough, J., Langematz, U., Manzini, E., Sassi, F., and Shibata, K.: Simulations of anthropogenic change in the strength of the Brewer-Dobson circulation, Clim. Dynam., 27, 727-741, doi:10.1007/s00382-006-0162-4, 2006.

Butchart, N., Cionni, I., Eyring, V., Shepherd, T. G., Waugh, D. W., Akiyoshi, H., Austin, J., Brühl, C., Chipperfield, M. P., Cordero, E., Dameris, M., Deckert, R., Dhomse, S., Frith, S. M., Garcia, R. R., Gettelman, A., Giorgetta, M. A., Kinnison, D. E., Li, F., Mancini, E., McLandress, C., Pawson, S., Pitari, G., Plummer, D. A., Rozanov, E., Sassi, F., Scinocca, J. F., Shibata, K., Steil, B., and Tian, W.: Chemistry-Climate Model Simulations of TwentyFirst Century Stratospheric Climate and Circulation Changes, J. Climate, 23, 5349-5374, doi:10.1175/2010JCLI3404.1, 2010.

Calvo, N., Garcia, R. R., Randel, W. J., and Marsh, D. R.: Dynamical Mechanism for the increase in tropical upwelling in the lowermost tropical stratosphere during warm ENSO events, J. Atmos. Sci., 67, 2331-2340, doi:10.1175/2010JAS3433.1, 2010.

Carslaw, D. C.: On the changing seasonal cycles and trends of ozone at Mace Head, Ireland, Atmos. Chem. Phys., 5, 34413450, doi:10.5194/acp-5-3441-2005, 2005.

Collins, W. J., Derwent, R. G., Garnier, B., Johnson, C. E., Sanderson, M. G. and Stevenson, D. S.: Effect of stratospheretroposphere exchange on the future tropospheric ozone trend, J. Geophys. Res., 108, 8528, doi:10.1029/2002JD002617, 2003.

Collins, W. D., Rasch, P. J., Boville, B. A., Hack, J. J., McCaa, J. R., Williamson, D. L., and Briegleb, B. P.: The Formulation and Atmospheric Simulation of the Community Atmosphere Model Version 3 (CAM3), J. Climate, 19, 2144-2161, doi:10.1175/JCLI3760.1, 2006.

Cooper, O. R., Parrish, D. D., Stohl, A., Trainer, M., Nédélec, P., Thouret, V., Cammas, J. P., Oltmans, S. J., Johnson, B. J., and Tarasick, D.: Increasing springtime ozone mixing ratios in the free troposphere over western North America, Nature, 463, 344348, 2010.

Cui, J., Pandey Deolal, S., Sprenger, M., Henne, S., Staehelin, J., Steinbacher, M., and Nédélec, P.: Free tropospheric ozone changes over Europe as observed at Jungfraujoch (1990-2008): an analysis based on backward trajectories, J. Geophys. Res., 116, D10304, doi:10.1029/2010JD015154, 2011.

Creilson, J. K., Fishman, J., and Wozniak, A. E.: Intercontinental transport of tropospheric ozone: a study of its seasonal variability across the North Atlantic utilizing tropospheric ozone residuals and its relationship to the North Atlantic Oscillation, Atmos. Chem. Phys., 3, 2053-2066, doi:10.5194/acp-3-2053-2003, 2003.

Creilson, J. K., Fishman, J., and Wozniak, A. E.: Arctic Oscillationinduced variability in satellite-derived tropospheric ozone, Geophys. Res. Lett., 32, L14822, doi:10.1029/2005GL023016, 2005.

Danielsen, E. F.: Stratospheric-tropospheric exchange based on radioactivity, ozone and potential vorticity, J. Atmos. Sci., 25, 502-518, doi:10.1175/15200469(1968)025<0502:STEBOR>2.0.CO;2, 1968.

Derwent, R. G., Simmonds, P. G., Manning, A. J., and Spain, T. G.: Trends over a 20-year period from 1987 to 2007 in surface ozone at the atmospheric research station, Mace Head, Ireland, Atmos. Environ., 41, 9091-9098, 2007.

Derwent, R. G., Manning, A. J., Simmonds, P. G., Spain, T. G., and O'Doherty, S.: Analysis and interpretation of 25 years of ozone observations at the Mace Head Atmospheric Research Station on the Atlantic Ocean coast of Ireland from 1987 to 2012, Atmos. Environ., 80, 361-368, doi:10.1016/j.atmosenv.2013.08.003, 2013.

Dlugokencky, E. J., Nisbet, E. G., Fisher, R., and Lowry, D.: Global atmospheric methane: budget, changes and dangers, Philos. T. R. Soc. A, 369, 2058-2072, doi:10.1098/rsta.2010.0341, 2011.

Doherty, R. M., Stevenson, D. S., Johnson, C. E., Collins, W. J., and Sanderson, M. G.: Tropospheric ozone and el Niño-Southern Oscillation: Influence of atmospheric dynamics, biomass burning emissions, and future climate change, J. Geophys. Res., 111, D19304, doi:10.1029/2005JD006849, 2006.

EPA: National air pollutant emission trends: 1900-1998, EPA Report 454/R-00-002, United States Environmental Protection Agency, Research Triangle Park, NC 27711, 2000.

Eyring, V., Chipperfield, M. P., Giorgetta, M. A., Kinnison, D. E., Manzini, E., Matthes, K., Newman, P. A., Pawson, S., Shepherd, T. G., and Waugh, D. W.: Overview of the New CCMVal Reference and Sensitivity Simulations in Support of Upcoming Ozone and Climate Assessments and the Planned SPARC CCMVal Report, SPARC Newsletter No. 30, 20-26, 2008.

Eyring, V., Cionni, I., Bodeker, G. E., Charlton-Perez, A. J., Kinnison, D. E., Scinocca, J. F., Waugh, D. W., Akiyoshi, H., Bekki, S., Chipperfield, M. P., Dameris, M., Dhomse, S., Frith, S. M., Garny, H., Gettelman, A., Kubin, A., Langematz, U., Mancini, E., Marchand, M., Nakamura, T., Oman, L. D., Pawson, S., Pitari, G., Plummer, D. A., Rozanov, E., Shepherd, T. G., Shibata, K., Tian, W., Braesicke, P., Hardiman, S. C., Lamarque, J. F., Morgenstern, O., Pyle, J. A., Smale, D., and Yamashita, Y.: Multimodel assessment of stratospheric ozone return dates and ozone recovery in CCMVal-2 models, Atmos. Chem. Phys., 10, 94519472, doi:10.5194/acp-10-9451-2010, 2010.

Fiore, A. M., Dentener, F. J., Wild, O., Cuvelier, C., Schultz, M. G., Hess, P., Textor, C., Schulz, M., Doherty, R. M., and Horowitz, L. W.: Long-range transport, tropospheric ozone, pollution, J. Geophys. Res., 114, D04301, doi:10.1029/2008JD010816, 2009.

Garcia, R. R., Marsh, D. R., Kinnison, D. E., Boville, B. A., and Sassi, F.: Simulation of secular trends in the middle atmosphere, 1950-2003, J. Geophys. Res., 112, D09301, doi:10.1029/2006JD007485, 2007.

Gettleman, A., Holton, J. R., and Rosenlof, H.: Mass fluxes of $\mathrm{O}_{3}$, $\mathrm{CH}_{4}, \mathrm{~N}_{2} \mathrm{O}$ and $\mathrm{CF}_{2} \mathrm{Cl} 2$ in the lower stratosphere calculated from observational data, J. Geophys. Res., 102, 19149-19159, 1997.

Gilge, S., Plass-Duelmer, C., Fricke, W., Kaiser, A., Ries, L., Buchmann, B., and Steinbacher, M.: Ozone, carbon monoxide and nitrogen oxides time series at four alpine GAW mountain stations in central Europe, Atmos. Chem. Phys., 10, 12295-12316, doi:10.5194/acp-10-12295-2010, 2010.

Hardiman, S. C., Butchart, N., and Calvo, N.: The morphology of the Brewer-Dobson circulation and its response to climate change in CMIP5 simulations, Q. J. Roy. Meteor. Soc., 140: 1958-1965, doi:10.1002/qj.2258, 2014.

Hegglin, M. I. and Shepherd, T. G.: Large climate-induced changes in ultraviolet index and stratosphere-to-troposphere ozone flux, Nat. Geosci., 2, 687-691, doi:10.1038/ngeo604, 2009. 
Hess, P. G. and Lamarque, J.-F.: Ozone source attribution and its modulation by the Arctic oscillation during the spring months, J. Geophys. Res., 112, 1-17, doi:10.1029/2006JD007557, 2007.

Hess, P. G. and Zbinden, R.: Stratospheric impact on tropospheric ozone variability and trends: 1990-2009, Atmos. Chem. Phys., 13, 649-674, doi:10.5194/acp-13-649-2013, 2013.

Hsu, J. and Prather, M. J.: Stratospheric variability and tropospheric ozone, J. Geophys. Res., 114, D06102, doi:10.1029/2008JD010942, 2009.

Jaffe, D., Chand, D., Hafner, W., Westerling, A., and Spracklen, D.: Influence of fires on $\mathrm{O}_{3}$ concentrations in the western US, Environ. Sci. Technol., 42, 5885-5891, 2008.

James, P.: A 15-year climatology of stratosphere-troposphere exchange with a Lagrangian particle dispersion model 2. Mean climate and seasonal variability, J. Geophys. Res., 108, 8522, doi:10.1029/2002JD002639, 2003.

Kinnison, D. E., Brasseur, G. P., Walters, S., Garcia, R. R., Marsh, D. R., Sassi, F., Harvey, V. L., Randall, C. E., Emmons, L., Lamarque, J. F., Hess, P., Orlando, J. J., Tie, X. X., Randel, W., Pan, L. L., Gettelman, A., Granier, C., Diehl, T., Niemeier, U., and Simmons, A. J.: Sensitivity of chemical tracers to meteorological parameters in the MOZART-3 chemical transport model, J. Geophys. Res., 112, D20302, doi:10.1029/2006JD007879, 2007.

Konovalov, I. B., Beekmann, M., Kuznetsova, I. N., Yurova, A., and Zvyagintsev, A. M.: Atmospheric impacts of the 2010 Russian wildfires: integrating modelling and measurements of an extreme air pollution episode in the Moscow region, Atmos. Chem. Phys., 11, 10031-10056, doi:10.5194/acp-11-10031-2011, 2011.

Koumoutsaris, S., Bey, I., Generoso, S., and Thouret, V.: Influence of El Niño-Southern Oscillation on the interannual variability of tropospheric ozone in the northern midlatitudes, J. Geophys. Res., 113, 1-21, doi:10.1029/2007JD009753, 2008.

Lamarque, J.-F. and Hess, P. G.: Model analysis of the temporal and geographical origin of the $\mathrm{CO}$ distribution during the TOPSE campaign, J. Geophys. Res., 108, 8354, doi:10.1029/2002JD002077, 2003.

Lamarque, J.-F., Hess, P., Emmons, L., Buja, L., Washington, W., and Granier, C.: Tropospheric ozone evolution between 1890 and 1990, J. Geophys. Res., 110, D08304, doi:10.1029/2004JD005537, 2005.

Lamarque, J.-F., Bond, T. C., Eyring, V., Granier, C., Heil, A., Klimont, Z., Lee, D., Liousse, C., Mieville, A., Owen, B., Schultz, M. G., Shindell, D., Smith, S. J., Stehfest, E., Van Aardenne, J., Cooper, O. R., Kainuma, M., Mahowald, N., McConnell, J. R., Naik, V., Riahi, K., and van Vuuren, D. P.: Historical (1850-2000) gridded anthropogenic and biomass burning emissions of reactive gases and aerosols: methodology and application, Atmos. Chem. Phys., 10, 7017-7039, doi:10.5194/acp10-7017-2010, 2010.

Lamarque, J.-F., Emmons, L. K., Hess, P. G., Kinnison, D. E., Tilmes, S., Vitt, F., Heald, C. L., Holland, E. A., Lauritzen, P. H., Neu, J., Orlando, J. J., Rasch, P. J., and Tyndall, G. K.: CAM-chem: description and evaluation of interactive atmospheric chemistry in the Community Earth System Model, Geosci. Model Dev., 5, 369-411, doi:10.5194/gmd-5-369-2012, 2012.

Langford, A. O., O'Leary, T. J., Masters, C. D., Aikin, K. C., and Proffitt, M. H.: Modulation of middle and up- per tropospheric ozone at northern midlatitudes by the El Niño/Southern Oscillation, Geophys. Res. Lett., 25, 2667-2670, doi:10.1029/98GL01909, 1998.

Leibensperger, E. M., Mickley, L. J., and Jacob, D. J.: Sensitivity of US air quality to mid-latitude cyclone frequency and implications of 1980-2006 climate change, Atmos. Chem. Phys., 8, 7075-7086, doi:10.5194/acp-8-7075-2008, 2008.

Levy, H., Mahlman, J. D., Moxim, W. J., and Liu, S. C.: Tropospheric ozone: the role of transport, J. Geophys. Res., 90, 3753, doi:10.1029/JD090iD02p03753, 1985.

Li, F., Stolarski, R. S., Pawson, S., Newman, P. A., and Waugh, D. W.: Narrowing of the upwelling branch of the BrewerDobson circulation and Hadley cell in chemistryclimate model simulations of the 21 st century, Geophys. Res. Lett., 37, 1-5, doi:10.1029/2010GL043718, 2010.

Li, Q.: Transatlantic transport of pollution and its effects on surface ozone in Europe and North America, J. Geophys. Res., 107, 4166, doi:10.1029/2001JD001422, 2002.

Liang, Q., Douglass, A. R., Duncan, B. N., Stolarski, R. S., and Witte, J. C.: The governing processes and timescales of stratosphere-to-troposphere transport and its contribution to ozone in the Arctic troposphere, Atmos. Chem. Phys., 9, 30113025, doi:10.5194/acp-9-3011-2009, 2009.

Lin, M., Fiore, A. M., Cooper, O. R., Horowitz, L. W., Langford, A. O., Levy, H., Johnson, B. J., Naik, V., Oltmans, S. J., and Senff, C. J.: Springtime high surface ozone events over the western United States: quantifying the role of stratospheric intrusions, J. Geophys. Res., 117, D00V22, doi:10.1029/2012JD018151, 2012.

Lin, M., Horowitz, L. W., Oltmans, S. J., Fiore, A. M., and Fan, S.: Tropospheric ozone trends at Mauna Loa Observatory tied to decadal climate variability, Nat. Geosci., 7, 136-143, doi:10.1038/ngeo2066, 2014.

Lin, S.-J.: A "Vertically Lagrangian" Finite-Volume Dynamical Core for Global Models, Mon. Weather Rev., 132, 2293-2307, doi:10.1175/1520-0493(2004)132<2293:AVLFDC>2.0.CO;2, 2004.

Logan, J. A., Staehelin, J., Megretskaia, I. A., Cammas, J.-P., Thouret, V., Claude, H., De Backer, H., Steinbacher, M., Scheel, H.-E., Stübi, R., Fröhlich, M., and Derwent, R.: Changes in ozone over Europe: analysis of ozone measurements from sondes, regular aircraft (MOZAIC) and alpine surface sites, J. Geophys. Res., 117, D09301, doi:10.1029/2011JD016952, 2012.

Marenco, A., Gouget, H., Nédélec, P., Pagés, J.-P., and Karcher, F.: Evidence of a long-term increase in tropospheric ozone from Pic du Midi data series: consequences: positive radiative forcing, J. Geophys. Res., 99, 16617-16632, doi:10.1029/94JD00021, 1994.

Mickley, L. J., Jacob, D. J., and Rind, D.: Uncertainty in preindustrial abundance of tropospheric ozone: Implications for radiative forcing calculations, J. Geophys. Res., 106, 3389, doi:10.1029/2000JD900594, 2001.

Neu, J. L., Flury, T., Manney, G. L., Santee, M. L., Livesey, N. J., and Worden, J.: Tropospheric ozone variations governed by changes in stratospheric circulation, Nat. Geosci., 7, 340-344, doi:10.1038/NGEO2138, 2014.

Ohara, T., Akimoto, H., Kurokawa, J., Horii, N., Yamaji, K., Yan, X., and Hayasaka, T.: An Asian emission inventory of anthropogenic emission sources for the period 1980-2020, At- 
mos. Chem. Phys., 7, 4419-4444, doi:10.5194/acp-7-4419-2007, 2007.

Oltmans, S. J., Johnson, B. J., and Harris, J. M.: Springtime boundary layer ozone depletion at Barrow, Alaska: meteorological influence, year-to-year variation, and long-term change, J. Geophys. Res., 117, D00R18, doi:10.1029/2011JD016889, 2012.

Oman, L. D., Plummer, D. A., Waugh, D. W., Austin, J., Scinocca, J. F., Douglass, A. R., Salawitch, R. J., Canty, T., Akiyoshi, H., Bekki, S., Braesicke, P., Butchart, N., Chipperfield, M. P., Cugnet, D., Dhomse, S., Eyring, V., Frith, S., Hardiman, S. C., Kinnison, D. E., Lamarque, J.-F., Mancini, E., Marchand, M., Michou, M., Morgenstern, O., Nakamura, T., Nielsen, J. E., Olivié, D., Pitari, G., Pyle, J., Rozanov, E., Shepherd, T. G., Shibata, K., Stolarski, R. S., Teyssédre, H., Tian, W., Yamashita, Y., and Ziemke, J. R.: Multimodel assessment of the factors driving stratospheric ozone evolution over the 21st century, J. Geophys. Res., 115, D24306, doi:10.1029/2010JD014362, 2010.

Ordóñez, C., Brunner, D., Staehelin, J., Hadjinicolaou, P., Pyle, J. A., Jonas, M., Wernli, H., and Prévôt, A. S. H.: Strong influence of lowermost stratospheric ozone on lower tropospheric background ozone changes over Europe, Geophys. Res. Lett., 34, 1-5, doi:10.1029/2006GL029113, 2007.

Parrish, D. D., Law, K. S., Staehelin, J., Derwent, R., Cooper, O. R., Tanimoto, H., Volz-Thomas, A., Gilge, S., Scheel, H.-E., Steinbacher, M., and Chan, E.: Long-term changes in lower tropospheric baseline ozone concentrations at northern mid-latitudes, Atmos. Chem. Phys., 12, 11485-11504, doi:10.5194/acp-1211485-2012, 2012.

Parrish, D. D., Lamarque, J.-F., Naik, V., Horowitz, L., Shindell, D. T., Staehelin, J., Derwent, R., Cooper, O. R., Tanimoto, A., Volz-Thomas, A., Gilge, S., Scheel, H.-E., Steinbacher, M., and Frohlich, M.: Long-term changes in lower tropospheric baseline ozone concentrations: comparing chemistry-climate models and observations at northern midlatitudes, J. Geophys. Res., 119, 5719-5736, doi:10.1002/2013JD021435, 2014.

Pozzoli, L., Janssens-Maenhout, G., Diehl, T., Bey, I., Schultz, M. G., Feichter, J., Vignati, E., and Dentener, F.: Re-analysis of tropospheric sulfate aerosol and ozone for the period 1980-2005 using the aerosol-chemistry-climate model ECHAM5-HAMMOZ, Atmos. Chem. Phys., 11, 9563-9594, doi:10.5194/acp-11-95632011, 2011.

Sander, S. P., Friedl, R. R., Golden, D. M., Kurylo, M. J., Moortgat, G. K., Keller-Rudek, H., Wine, P. H., Ravishankara, A. R., Kolb, C. E., Molina, M. J., Finlayson-Pitts, B. J., Huie, R. E., and Orkin, V. L.: Chemical Kinetics and Photochemical Data for Use in Atmospheric Studies, Evaluation Number 15, JPL Publication 06-2, Jet Propulsion Laboratory, Pasadena, CA, 2006.

Sassi, F., Boville, B. A., Kinnison, D., and Garcia, R. R.: The effects of interactive ozone chemistry on simulations of the middle atmosphere, Geophys. Res. Lett., 32, L07811, doi:10.1029/2004GL022131, 2005.

Simmonds, P. G., Derwent, R. G., Manning, A. L., and Spain, G.: Significant growth in surface ozone at Mace Head, Ireland, 1987-2003, Atmos. Environ., 38, 4769-4778, doi:10.1016/j.atmosenv.2004.04.036, 2004.

Shindell, D. T., Faluvegi, G., Unger, N., Aguilar, E., Schmidt, G. A., Koch, D. M., Bauer, S. E., and Miller, R. L.: Simulations of preindustrial, present-day, and 2100 conditions in the NASA GISS composition and climate model G-PUCCINI, At- mos. Chem. Phys., 6, 4427-4459, doi:10.5194/acp-6-4427-2006, 2006.

SPARC-CCMVal: SPARC Report on the Evaluation of ChemistryClimate Models, edited by: Eyring, V., Shepherd, T. G., Waugh, D. W., SPARC Report No. 5, WCRP-132, WMO/TD-No. 1526, 2010.

Sprenger, M.: A northern hemispheric climatology of crosstropopause exchange for the ERA15 time period (1979-1993), J. Geophys. Res., 108, 8521, doi:10.1029/2002JD002636, 2003.

Stevenson, D. S., Dentener, F. J., Schultz, M. G., Ellingsen, K., van Noije, T. P. C., Wild, O., Zeng, G., Amann, M., Atherton, C. S., Bell, N., Bergmann, D. J., Bey, I., Butler, T., Cofala, J., Collins, W. J., Derwent, R. G., Doherty, R. M., Drevet, J., Eskes, H. J., Fiore, A. M., Gauss, M., Hauglustaine, D. A., Horowitz, L. W., Isaksen, I. S. A., Krol, M. C., Lamarque, J.-F., Lawrence, M. G., Montanaro, V., Müller, J.-F., Pitari, G., Prather, M. J., Pyle, J. A., Rast, S., Rodriguez, J. M., Sanderson, M. G., Savage, N. H., Shindell, D. T., Strahan, S. E., Sudo, K., and Szopa, S.: Multimodel ensemble simulations of present-day and near-future tropospheric ozone, J. Geophys. Res., 111, D08301, doi:10.1029/2005JD006338, 2006.

Tang, Q., Hess, P. G., Brown-Steiner, B., and Kinnison, D. E.: Tropospheric ozone decrease due to the Mount Pinatubo eruption: reduced stratospheric influx, Geophys. Res. Lett., 40, 55535558, doi:10.1002/2013GL056563, 2013.

Tarasick, D. W.: Changes in the vertical distribution of ozone over Canada from ozonesondes: 1980-2001, J. Geophys. Res., 110, D02304, doi:10.1029/2004JD004643, 2005.

Terao, Y., Logan, J. A., Douglass, A. R., and Stolarski, R. S.: Contribution of stratospheric ozone to the interannual variability of tropospheric ozone in the northern extratropics, J. Geophys. Res., 113, 1-9, doi:10.1029/2008JD009854, 2008.

Thouret, V., Cammas, J.-P., Sauvage, B., Athier, G., Zbinden, R., Nédélec, P., Simon, P., and Karcher, F.: Tropopause referenced ozone climatology and inter-annual variability (1994-2003) from the MOZAIC programme, Atmos. Chem. Phys., 6, 1033-1051, doi:10.5194/acp-6-1033-2006, 2006.

Tressol, M., Ordonez, C., Zbinden, R., Brioude, J., Thouret, V., Mari, C., Nedelec, P., Cammas, J.-P., Smit, H., Patz, H.-W., and Volz-Thomas, A.: Air pollution during the 2003 European heat wave as seen by MOZAIC airliners, Atmos. Chem. Phys., 8, 2133-2150, doi:10.5194/acp-8-2133-2008, 2008.

Turner, A. J., Fiore, A. M., Horowitz, L. W., and Bauer, M.: Summertime cyclones over the Great Lakes Storm Track from 1860-2100: variability, trends, and association with ozone pollution, Atmos. Chem. Phys., 13, 565-578, doi:10.5194/acp-13565-2013, 2013.

Vestreng, V., Ntziachristos, L., Semb, A., Reis, S., Isaksen, I. S. A., and Tarrasón, L.: Evolution of $\mathrm{NO}_{\mathrm{x}}$ emissions in Europe with focus on road transport control measures, Atmos. Chem. Phys., 9, 1503-1520, doi:10.5194/acp-9-1503-2009, 2009.

Volz, A. and Kley, D.: Evaluation of the Montsouris series of ozone measurements made in the nineteenth century, Nature, 332, 240242, doi:10.1038/332240a0, 1988.

Voulgarakis, A., Hadjinicolaou, P., and Pyle, J. A.: Increases in global tropospheric ozone following an El Niño event: examining stratospheric ozone variability as a potential driver, Atmos. Sci. Lett., 12, 228-232, doi:10.1002/asl.318, 2011. 
Wilson, R. C., Fleming, Z. L., Monks, P. S., Clain, G., Henne, S., Konovalov, I. B., Szopa, S., and Menut, L.: Have primary emission reduction measures reduced ozone across Europe? An analysis of European rural background ozone trends 1996-2005, Atmos. Chem. Phys., 12, 437-454, doi:10.5194/acp-12-437-2012, 2012.

WMO (World Meteorological Organization), Scientific Assessment of Ozone Depletion: 2006, Global Ozone Research and Monitoring Project-Report No. 50, 572 pp., Geneva, Switzerand, 2007.
Zbinden, R. M., Cammas, J.-P., Thouret, V., Nédélec, P., Karcher, F., and Simon, P.: Mid-latitude tropospheric ozone columns from the MOZAIC program: climatology and interannual variability, Atmos. Chem. Phys., 6, 1053-1073, doi:10.5194/acp-6-1053-2006, 2006.

Zeng, G. and Pyle, J. A.: Influence of El Niño Southern Oscillation on stratosphere/troposphere exchange and the global tropospheric ozone budget, Geophys. Res. Lett., 32, L01814, doi::10.1029/2004GL021353, 2005. 